\title{
Uchylanie się od obowiązku służby wojskowej w orzecznictwie Wojskowego Sądu Garnizonowego w Białymstoku w latach 1944-1945 na przykładzie wybranych spraw
}

W ostatnich latach znacznie rozwinęły się badania z zakresu sądownictwa wojskowego, czego owocem są liczne opracowania, jednak skupiają się one przede wszystkim wokół zagadnień związanych z funkcjonowaniem w latach 1946-1955 wojskowych sądów rejonowych. Tą tematyką zajmował się m.in. Rafał Leśkiewicz, Bohdan Łukaszewicz, Filip Musiał, Radosław Ptaszyński czy Joanna Żelaz$\mathrm{ko}^{1}$. Na marginesie zainteresowań badaczy znajdowały się natomiast wojskowe sądy garnizonowe, których działalność przypadała na lata 1944-1946 i poprzedzała funkcjonowanie wojskowych sądów rejonowych. Nieliczne prace z tego zakresu ${ }^{2}$ mogą stanowić jedynie punkt wyjścia do pogłębienia badań nad strukturą i działalnością wojskowych sądów garnizonowych, do których należy Wojskowy Sąd Garnizonowy w Białymstoku (dalej jako WSG). W czasie swojego funkcjo-

${ }^{1}$ R. Leśkiewicz, Wojskowy Sąd Rejonowy w Poznaniu (1946-1955). Organizacja, funkcjonowanie, procesy aktotwórcze, Warszawa-Poznań 2009; B. Łukaszewicz, Wojskowy Sąd Rejonowy w Olsztynie 1946-1955. Szkice do monografii, Olsztyn 2000; F. Musiał, Polityka czy Sprawiedliwość. Wojskowy Sąd Rejonowy w Krakowie (1946-1955), Kraków 2005; R. Ptaszyński, Wojskowy Sąd Rejonowy $i$ Wojskowa Prokuratura Rejonowa w Szczecinie w latach 1946-1955, Szczecin 2010; K. Szwagrzyk, Sędziowie Wojskowego Sądu Rejonowego w Szczecinie i ich wyroki, Szczecin 2008; J. Żelazko, Ludowa „Sprawiedliwość”. Skazani przez Wojskowy Sąd Rejonowy w Lodzi (19461955), Łódź 2007.

2 J. Borowiec, Aparat bezpieczeństwa a wojskowy wymiar sprawiedliwości. Rzeszowszczyzna 1944-1954, Warszawa 2004; B. Dzięcioł, Sądy wojskowe Polski Lubelskiej (lipiec-grudzień 1944), Warszawa 2001; B. Dzięcioł, Sądownictwo wojenne w czasie walk frontowych (12 stycznia - 8 maja 1945 r.), Warszawa 2001; Z. Leszczyńska, Prokuratorzy i sędziowie lubelskich sądów wojskowych 1944-1955, Lublin 2006; K. Szwagrzyk, Prawnicy czasu bezprawia. Sędziowie i prokuratorzy wojskowi w Polsce 1944-1956, Kraków-Wrocław 2005. 
nowania, tj. w latach 1944-1946 sąd ten rozpoznał co najmniej 826 spraw³ ${ }^{3}$ wśród których były również dotyczące uchylania się od obowiązku służby wojskowej. Wypada zaznaczyć, że nie wszystkie akta spraw sądowych rozpatrywanych przed WSG w latach 1944-1946 zachowały się do naszych czasów, co z kolei uniemożliwia jednoznaczne stwierdzenie, ile ostatecznie Sąd wydał wyroków co do osób uchylających się od służby wojskowej z tytułu niezadośćuczynienia przez poborowych obowiązkowi mobilizacji lub rejestracji w komendach wojskowych. $\mathrm{Z}$ analizy zostały wyłączone sprawy dotyczące przypadków dezercji. W zasobie archiwalnym Oddziału Instytutu Pamięci Narodowej w Białymstoku zachowało się jedynie 317 akt spraw WSG, w tym 48 akt spraw, które zawierają wyroki odnośnie uchylania się przez poborowych od służby wojskowej. W większości tych spraw osoby ponosiły odpowiedzialność zarówno z uwagi na naruszenie art. 118 $\S 1 \mathrm{KKWP}^{4} \mathrm{~W}$ zW. z art. 117 § 1 i 2 KKWP, jak również przepisów Dekretu PKWN z dnia 30 października 1945 r. o ochronie Państwa ${ }^{5}$ i jedynie w 8 przypadkach wyrok został wydany wyłącznie w oparciu o art. 118 § KKWP w zw. z art. $117 \S 1$ i 2 KKWP. Wszystkie niżej analizowane sprawy datowane są na lata 1944-1945 mimo że WSG funkcjonował do marca 1946 r., i w tym czasie również orzekał. W końcowej fazie jego urzędowania brak spraw, w których wyroki były wydawane jedynie na podstawie art. $118 \S 1$ KKWP w zw. z art. $117 \S 1$ i 2 KKWP. Przy omawianiu konkretnych spraw podano zarówno przyczyny i sposoby działania osób skazanych, mające na celu uchylenie się od obowiązku służby wojskowej, jak również orzeczony przez Sąd wymiar kary.

Dekretem PKWN z dnia 23 września 1944 r. wprowadzono Prawo o ustroju Sądów Wojskowych i Prokuratury Wojskowej, którego przepisy weszły w życie z dniem 30 września 1944 r. ${ }^{6}$ Zanim jednak zaczęły one obowiązywać, wojskowe sądy garnizonowe tworzono na podstawie rozkazu nr 15 Naczelnego Dowódcy WP z dnia 2 września 1944 r. W oparciu o pkt 3 ppkt 5 tego rozkazu powołano do życia wojskowe sądy garnizonowe, które miały funkcjonować w miejscach stacjonowania dowództw poszczególnych garnizonów . Utworzenie poszczegól-

${ }^{3}$ P. Łapiński, Sadownictwo wojskowe $w$ województwie białostockim w latach 1944-1955 (zarys problematyki) [w:] K. Sychowicz, E. Świętochowska-Bobowik, W.F. Wilczewski (red.), Polska pótnocno-wschodnia w okresie stalinizmu - spojrzenie z perspektywy pótwiecza, Białystok-Warszawa 2009 , s. 29.

${ }^{4}$ Dekret PKWN z dnia 23 września 1944 r. Kodeks Karny Wojska Polskiego, Dz.U. z 1944 r., nr 6 poz. 27.

${ }^{5}$ Dekret PKWN z dnia 30 października 1944 r. o ochronie Państwa, Dz.U. z 1944, nr 10 poz. 50.

${ }^{6}$ Dekret PKWN z dnia 23 września 1944 r. Prawo o ustroju Sądów Wojskowych i Prokuratury Wojskowej, Dz.U. z 1944 r., nr 6 poz. 29.

7 Według hasła w elektronicznej Encyklopedii PWN, garnizon jest to obszar, na którym stale lub czasowo przebywają oddziały lub znajdują się zakłady i instytucje wojskowe, https://encyklopedia.pwn.pl/haslo/garnizon;3904117.html [dostęp: 17.09.2019]. 
nych wojskowych sądów garnizonowych było natomiast uzależnione od wydania w tej kwestii stosownego rozkazu przez Naczelnego Dowódcę WP. Pierwszym wojskowym sądem garnizonowym utworzonym w oparciu o pkt 5 rozkazu $\mathrm{Nr}$ 15 Naczelnego Dowódcy WP z dnia 2 września 1944 r. był Wojskowy Sąd Garnizonowy w Lublinie. Następnie na podstawie rozkazu nr 28 z dnia 17 września 1944 r. Naczelnego Dowódcy WP powołano do życia kolejny wojskowy sąd garnizonowy: Wojskowy Sąd Garnizonowy w Białymstoku - miano go utworzyć do 25 września 1944 r. W dniach 21 oraz 23 września 1944 r. dokonano obsady kadrowej białostockiego sądu - wówczas to jego szefem został mjr Bronisław Rakowski ${ }^{8}$, na którego zastępcę powołano por. Natana Batlera ${ }^{9}$, natomiast ppor. Stanisława Tudruja ${ }^{10}$ wyznaczono na stanowisko sędziego ${ }^{11}$. Rakowski został przeniesiony na stanowisko prezesa Wojskowego Sądu Okręgowego w Krakowie już w pierwszym kwartale 1945 r. Wówczas przez krótki czas obowiązki szefa WSG pełnił kpt. Natan Batler, który w ślad za swoim poprzednikiem został również przeniesiony do Krakowa na stanowisko sędziego Wojskowego Sądu Okręgowe-

${ }^{8}$ Bronisław Rakowski s. Józefa ur. 3 września 1982 r. w Dźwińsku. W 1942 ukończył dwuletni kurs prawniczy w Instytucie Prawnym w Moskwie. Członek Sądu i prezes Trybunału Wojsk NKWD w latach 1936-1943. W sierpniu 1944 r. skierowany do służby w Wojsku Polskim, od 13 września 1944 r. do 23 września 1944 r. sędzia Wojskowego Sądu Garnizonowego w Lublinie, od 23 września 1944 r. do 20 lutego 1945 r. szef Wojskowego Sądu Garnizonowego w Białymstoku, od 22 lutego 1945 r. do 18 lutego 1946 r. szef Wojskowego Sądu Okręgowego nr I w Krakowie, a następnie od 19 lutego 1946 r. do sierpnia 1947 r. szef Wojskowego Sądu Okręgowego w Warszawie. We wrześniu 1947 r. odesłany do ZSRS na własną prośbę z uwagi na problemy zdrowotne. (szerzej zob. K. Szwagrzyk, Prawnicy czasu bezprawia. Sędziowie i prokuratorzy wojskowi w Polsce 1944-1946, Kraków-Wrocław 2005, s. 410).

9 Natan Batler (Antoni Batler) s. Natana ur. 7 kwietnia 1896 r. w Brodach. W 1922 ukończył prawo na Uniwersytecie Jana Kazimierza we Lwowie. W latach 1928-1939 wykonywał zawód adwokata we Lwowie, będąc jednocześnie starszym asystentem na Wydziale Prawa Uniwersytetu Jana Kazimierza. Od 16 sierpnia 1944 r. służył w Wojsku Polskim. W okresie od 23 września 1944 r. do 12 marca 1945 r. zastępca szefa WSG, od 12 marca 1945 r. do 31 grudnia 1945 r. sędzia Wojskowego Sądu Okręgowego nr V w Krakowie, od 19 lutego 1946 r. do 6 września 1946 r. zastępca szefa Wojskowego Sądu Rejonowego w Krakowie. Po zakończeniu kariery wojskowej ponownie wykonywał zawód adwokata (szerzej zob. K. Szwagrzyk, Prawnicy czasu bezprawia ..., s. 266-267).

${ }^{10}$ Stanisław Tudruj s. Pawła ur. 21 października 1910 r. w Stasinie. W 1938 ukończył prawo na Katolickim Uniwersytecie Lubelskim. Od 11 września 1944 r. rozpoczął jako ochotnik służbę w Wojsku Polskim. Od września 1944 r. do marca 1945 r. sędzia, a następnie od 12 marca 1945 r. do 19 lutego 1946 r. szef WSG, od 19 lutego 1946 r. do 12 sierpnia 1947 r. zastępca szefa Wojskowego Sądu Okręgowego nr II w Bydgoszczy z siedzibą w Koszalinie, od 12 sierpnia 1947 r. do 8 stycznia 1948 r. zastępca szefa Wojskowego Sądu Rejonowego w Bydgoszczy, od 9 stycznia 1948 r. do 2 lutego 1949 r. zastępca szefa Wojskowego Sądu Okręgowego nr I w Warszawie. Z dniem 5 kwietnia 1949 r. przeniesiony do rezerwy (szerzej zob. K. Szwagrzyk, Prawnicy czasu bezprawia..., s. 452-453).

${ }^{11}$ M. Zaborski, Ustrój sądów wojskowych w Polsce w latach 1944-1955, Lublin 2005, s. 201202. 
go $^{12}$. Stanisław Tudruj kierował pracami WSG od 12 marca 1945 r. do roku $1946^{13}$. $\mathrm{Na}$ mocy rozkazu personalnego $\mathrm{nr} 105$ wydanego przez Naczelnego Dowódcę WP gen. Michała Żymierskiego z dniem 19 lutego 1946 r. został przeniesiony na stanowisko zastępcy szefa Wojskowego Sądu Okręgowego w Koszalinie ${ }^{14}$. Jednakże z zachowanych materiałów archiwalnych wynika, że obowiązki szefa WSG pełnił jeszcze w marcu 1946 r., świadczy o tym m.in. podpisany przez niego 4 marca 1946 r. plan Pracy WSG na marzec - jeden z punktów przywoływanego planu mówił o rozformowaniu tego sądu i zorganizowaniu w jego miejsce do dnia 10 marca 1946 r. Wojskowego Sądu Rejonowego w Białymstoku ${ }^{15}$. Ponadto na dzień 4 marca 1946 r. datowane jest podpisane przez mjr. Stanisława Tudruja jako szefa WSG sprawozdanie z działalności sądu za luty 1946 r., którego jeden z egzemplarzy zgodnie z właściwością miał być przekazany do Najwyższego Sądu Wojskowego w Warszawie, a drugi do Wojskowego Sądu Okręgu Warszawskiego w Warszawie. W sprawozdaniu znalazła się informacja o wstrzymaniu prac WSG w zakresie rozpatrywania spraw w marcu 1946 r.: „Przerwa w rozpatrywaniu spraw będzie trwała do 8 marca 1946 r., w którym to czasie Sąd Garnizonowy zostanie przygotowany do likwidacji i poczynione będą przygotowania do zorganizowania Sądu Rejonowego" "16. Siedziba WSG od 30 września 1944 r. do 10 marca 1946 r. mieściła się w Białymstoku przy ul. Mickiewicza $15^{17}$. Pod tym adresem początkowo działał także Wojskowy Sąd Rejonowy w Białymstoku ${ }^{18}$. Według rozkazu nr 2 Naczelnego Dowódcy WP z 2 stycznia 1945 r. WSG swoją właściwością miał obejmować zarówno miasto, jak i powiat Białystok, a także powiaty: Augustów, Bielsk Podlaski, Łomża, Sokółka, Suwałki, Szczuczyn oraz Wysokie Mazowieckie ${ }^{19}$.

Zanim jednak utworzono WSG, został wydany Dekret PKWN z dnia 15 sierpnia 1944 r. o częściowej mobilizacji i rejestracji ludności do służby wojskowej,

12 T. Pogorzelska, Wojskowy Sad Rejonowy w Biatymstoku 1946-1955: organizacja, funkcjonowanie kancelarii i archiwizacja dokumentacji [w:] Przeglad Archiwalny Instytutu Pamięci Narodowej, Warszawa 2012, t. 5, s. 31.

13 P. Łapiński, op.cit., s. 27.

${ }^{14}$ AIPN Bi 172/11, Wyciąg z rozkazu personalnego Naczelnego Dowódcy Wojska Polskiego gen. Michała Żymierskiego nr 105 z dnia 19 lutego 1946 r. dotyczący mjr. Stanisława Tudruja, 19 II 1946, k. 34.

15 AIPN Bi 172/13, Plan pracy Wojskowego Sądu Garnizonowego w Białymstoku - na miesiąc marzec 1946 r., 4 III 1946 r., k. 29.

16 AIPN Bi 172/13, Sprawozdanie z działalności Wojskowego Sądu Garnizonowego w Białymstoku za miesiąc luty 1946 r., 4 III 1946 r., k. 31-32.

17 AIPN Bi 172/14, Meldunek dyslokacyjny Wojskowego Sądu Garnizonowego w Białymstoku na dzień 1 marca 1946. r., 1 III 1946 r., k. 10.

18 P. Łapiński, op.cit., s. 27.

19 M. Zaborski, op.cit., s. 204. 
który wszedł w życie 22 sierpnia 1944 r. ${ }^{20}$ Określono w nim osoby, które od 20 do 31 sierpnia 1944 r. należało powołać do służby wojskowej - mężczyzn zdolnych do służby wojskowej urodzonych w latach 1921-192421. Natomiast w terminie od 1 do 20 września 1944 r. miano przeprowadzić rejestrację mężczyzn urodzonych w latach 1911-192022. Jednocześnie w art. 9 Dekretu zapowiadano pociągnięcie do odpowiedzialności karnej osób podlegających mobilizacji lub rejestracji do służby wojskowej w przypadku uchybienia zawartym w nim przepisom: „Osoby, uchylające się od stawiennictwa zostaną pociągnięte do odpowiedzialności według prawa wojskowego" "23. Przed Wojskowym Sądem Garnizonowym w Białymstoku odpowiedzialność karną ponosić będą poborowi ze wskazanych w Dekrecie roczników.

Przepisy dotyczące obowiązku wojskowego zostały uregulowane ponadto w Dekrecie PKWN z dnia 23 września 1944 r. Kodeks Karny Wojska Polskiego, który wszedł w życie z dniem 30 września $1944 \mathrm{r}^{24} \mathrm{~W}$ rozdziale XIX tego aktu prawnego, w art. od 115 do 124 unormowano przestępstwa skierowane przeciwko obowiązkowi wojskowemu, w większości odnoszące się do żołnierzy, jednak znalazły się tam również przepisy dotyczące cywilów, którzy z uwagi na swój wiek byli zobowiązani odbyć służbę wojskową, i tak w art. 117 § 1 KKWP zapisano, że „kto będąc zobowiązany do służby wojskowej, nie czyni zadość powołaniu lub publicznemu wezwaniu do tej służby w terminie oznaczonym podlega karze więzienia do lat 2 albo karze aresztu lub skierowaniu do oddziału karnego"25. Z kolei $\S 2$ tego artykułu stanowi, że jeżeli przestępstwo to miało miejsce w czasie wojny, sprawca podlega karze więzienia albo karze śmierci, zgodnie zaś z $§ 3 \mathrm{w}$ przypadku nieumyślnego popełnienia przestępstwa sprawca podlega karze aresztu lub skierowaniu do oddziału karnego ${ }^{26}$. W art. $118 \S 1$ KKWP zapisano natomiast, że jeżeli sprawca dopuszcza się m.in. przestępstwa określonego w art. 117 KKWP w celu dłuższego lub trwałego uchylania się od obowiązku wojskowego podlega karze więzienia do lat 3, a w czasie wojny karze więzienia albo karze śmierci ${ }^{27}$.

Jednym z tych, którzy w 1944 r. zostali postawieni przed sądem za naruszenie art. 117 § 2 KKWP, tj. uchylanie się od obowiązku służby wojskowej w czasie wojny, był Wacław Matejczyk, który 1 września 1944 r. stawił się przed komi-

${ }^{20}$ Dekret PKWN z dnia 15 sierpnia 1944 r. o częściowej mobilizacji i rejestracji ludności do służby wojskowej, Dz.U. z 1944 r., nr 2 poz. 5.

${ }^{21}$ Ibidem, art. 1 pkt a.

${ }^{22}$ Ibidem, art. 2 pkt a.

${ }^{23}$ Ibidem, art. 9.

${ }^{24}$ Dekret PKWN z dnia 23 września 1944 r. Kodeks Karny Wojska Polskiego.

${ }^{25}$ Ibidem, art. $117 \S 1$.

${ }^{26}$ Ibidem, art. $117 \S 2$ i 3.

${ }^{27}$ Ibidem, art. $118 \S 1$. 
sją poborową Rejonowej Komisji Uzupełnień w Białymstoku, został uznany za zdolnego do odbycia służby wojskowej i w tym celu miał zgłosić się ponownie do komisji do 9 września 1944 r. ${ }^{28}$ Nie stawił się jednak w terminie w wyznaczonym miejscu - w konsekwencji został zatrzymany przez PUBP w Białymstoku i przekazany 7 grudnia 1944 r. do dyspozycji Rejonowej Komendy Uzupełnień w Białymstoku ${ }^{29}$. Sprawę Matejczyka skierowano do Wojskowej Prokuratury Garnizonowej w Białystoku, aby przeprowadzić postępowanie przygotowawcze, ponieważ już w trakcie zatrzymania podejrzanego okazało się, że zmienił rok urodzenia w swoim paszporcie niemieckim ${ }^{30}$. Umieszczono go w więzieniu Karno-Śledczym w Białymstoku, gdzie 19 grudnia 1944 r. został przesłuchany przez oficera śledczego Wojskowej Prokuratury Garnizonowej w Białymstoku ppor. Bronisława Świątnickiego ${ }^{31}$. W trakcie przesłuchania zatrzymany mówił, że nie stawił się przed komisją, ponieważ musiał zająć się pracą na roli, gospodarstwem i przygotować ziarno w ramach kontyngentu, bo jego ojciec z powodu choroby nie był zdolny do ciężkiej pracy. Co do zmiany roku urodzenia w paszporcie niemieckim twierdził, że zrobił to w maju 1944 r. z obawy przed wywiezieniem do Niemiec. Matejczyk twierdził, że nie posługiwał się tym paszportem przed polskimi władzami wojskowymi, którym podał właściwą datę urodzenia ${ }^{32}$. Oficer śledczy prowadzący postępowanie wydał postanowienie o zastosowaniu środka zapobiegawczego w postaci aresztu tymczasowego w Więzieniu Karno-Śledczym w Białymstoku ${ }^{33}$. Następnego dnia, 20 grudnia, ppor. Świątnicki wydał postanowienie o pociągnięciu Matejczyka do odpowiedzialności karnej z powodu niestawienia się w wyznaczonym terminie do odbycia służby wojskowej,

${ }^{28}$ AIPN Bi 212/3, Karta powołania nr 141 Rejonowej Komisji Uzupełnień w Białymstoku wydana Wacławowi Matejczykowi, 1 IX 1944 r., k. 19-20.

${ }^{29}$ Ibidem, Pismo kierownika PUBP w Białymstoku skierowane do Rejonowej Komendy Uzupełnień w Białymstoku dotyczące przekazania zatrzymanego Matejczyka Wacława, 7 XII 1944 r., k. 5 .

${ }^{30}$ Ibidem, Pismo Komendanta punktu zbornego Rejonowej Komisji Uzupełnień w Białymstoku do Wojskowej Prokuratury Garnizonowej w Białymstoku, 8 XII 1944 r., k. 4.

${ }^{31}$ Bronisław Świątnicki s. Jana ur. 29 września 1907 r. w Łodzi. W 1937 ukończył prawo na Uniwersytecie Stefana Batorego w Wilnie. W latach 1938-1939 pracował jako aplikant sądowy. Od listopada 1944 r. był ochotnikiem do służby w Wojsku Polskim. Od 12 grudnia 1944 do 15 marca 1945 r. oficer śledczy Wojskowej Prokuratury Garnizonowej w Białymstoku, a następnie od 15 marca 1945 r. do 1 kwietnia 1946 r. Wojskowej Prokuratury Garnizonowej w Rzeszowie. W okresie od 1 kwietnia 1946 r. do 10 maja 1947 r. zajmował stanowisko podprokuratora Wojskowej Rejonowej we Wrocławiu. Z dniem 10 maja 1947 r. przeniesiony do rezerwy (szerzej K. Szwagrzyk, Prawnicy czasu bezprawia..., s. 445).

32 AIPN Bi 212/3, Protokół przesłuchania Wacława Matejczyka przez oficera śledczego Wojskowej Prokuratury Garnizonowej w Białymstoku, 19 XII 1944 r., k. 9-10.

${ }_{33}$ Ibidem, Postanowienie oficera śledczego Wojskowej Prokuratury Garnizonowej w Białymstoku o zastosowaniu wobec Wacława Matejczyka środka zapobiegawczego w postaci aresztu tymczasowego, 19 XII 1944 r., k. 12. 
a tym samym naruszenie art. $117 \S 2 \mathrm{KKWP}^{34} .23$ grudnia 1944 r. sporządzono akt oskarżenia, w którym Matejczyka oskarżono o uchylanie się od służby wojskowej od 9 września do 7 grudnia 1944 r., tj. o popełnienie przestępstwa z art. 117 $\S 2$ KKWP. Jako dowód rzeczowy załączono kartę powołania Nr 141 Rejonowej Komisji Uzupełnień w Białymstoku ${ }^{35}$. Akt oskarżenia został jeszcze tego samego dnia zatwierdzony przez por. Władysława Oleckiego ${ }^{36}$ - prokuratora Wojskowej Prokuratury Garnizonowej w Białymstoku i sprawę według właściwości miano przekazać $\mathrm{WSG}^{37}$, co nastąpiło dopiero 28 grudnia $1944 \mathrm{r}^{38}$. Tego samego dnia odbyło się posiedzenie niejawne sądu, w którym udział wzięli ppłk Bronisław Rakowski jako przewodniczący oraz kpt. Natan Batler oraz podchor. Juliusz Krupski jako sędziowie ${ }^{39}$. Protokołował ppor. Józef Obuchowicz. Zatwierdzono akt oskarżenia, utrzymano w mocy areszt tymczasowy i wyznaczono rozprawę na 30 grud-

${ }^{34}$ Ibidem, Postanowienie oficera śledczego Wojskowej Prokuratury Garnizonowej w Białymstoku o pociągnięciu do odpowiedzialności karnej Wacława Matejczyka, 20 XII 1944 r., k. 11.

35 Ibidem, Akt oskarżenia przeciwko Wacławowi Matejczykowi sporządzony przez oficera śledczego oficera śledczego Wojskowej Prokuratury Garnizonowej w Białymstoku, 23 XII 1944 r., k. 22-23.

${ }^{36}$ Władysław Olecki s. Bolesława ur. 18 grudnia 1903 r. w Nowej Bielicy. Od 1 sierpnia 1943 r. odbywał służbę w Wojsku Polskim, od 11 grudnia 1943 r. do 16 kwietnia 1944 r. p.o. oficera śledczego Wojskowej Prokuratury 1. Korpusu PSZ w ZSRS, od 16 kwietnia 1944 r. do 16 sierpnia 1944 r. oficer śledczy Wojskowej Prokuratury 1. DP, a od 16 sierpnia 1944 r. do 23 września 1944 r. Wojskowej Prokuratur 3. DP, od 23 września 1944 r. do 19 lutego 1946 r. prokurator Wojskowej Prokuratury Garnizonowej w Białymstoku, a następnie do 18 kwietnia 1947 r. Wojskowej Prokuratury Rejonowej w Białymstoku. Od 18 kwietnia 1947 r. do 5 lutego 1948 r. prokurator Wojskowej Prokuratury Rejonowej w Olsztynie, od 1 marca 1948 r. do 20 kwietnia 1948 r. podprokurator Ekspozytury Wojskowej Prokuratury PKP w Katowicach, od 20 kwietnia 1948 r. do 5 sierpnia 1949 r. podprokurator Wojskowej Prokuratury Dyrekcji Okręgowej Kolei Państwowej w Katowicach. Od 6 sierpnia 1948 r. pozostawał w dyspozycji Departamentu Personalnego MON, a następnie z dniem 16 kwietnia 1951 r. przeniesiony w stan spoczynku (szerzej K. Szwagrzyk, Prawnicy czasu bezprawia..., s. 389).

37 AIPN Bi 212/3, Postanowienie o zatwierdzeniu aktu oskarżenia w sprawie Wacława Matejczyka, 23 XII 1944 r., k. 24.

${ }^{38}$ Ibidem, Pismo prokuratora wojskowego Wojskowej Prokuratury Garnizonowej w Białymstoku skierowane do Wojskowego Sądu Garnizonowego w Białymstoku, 28 XII 1944 r., k. 25.

39 Juliusz Krupski s. Władysława ur. 25 października 1912 r. w Zborowie. W 1936 ukończył prawo na Uniwersytecie Jana Kazimierza we Lwowie. W latach 1936-1937 był aplikantem sądowym w Sądzie Grodzkim we Lwowie. Od 24 sierpnia 1944 r. służba w Wojsku Polskim. W okresie od 9 listopada 1944 do 3 kwietnia 1946 r. sędzia Wojskowego Sądu Garnizonowego w Białymstoku, następnie od kwietnia 1946 r. do 21 marca 1947 r. sędzia Wojskowego Sądu Okręgowego nr IV we Wrocławiu, a od 22 marca 1947 r. do 5 stycznia 1949 r. szef Wojskowego Sądu Okręgowego nr VII w Lublinie. Od 6 stycznia 1949 r. do 1 kwietnia 1952 r. sędzia Wydziału II Najwyższego Sądu Wojskowego, następnie od 1 kwietnia 1952 r. do 1 grudnia 1952 r. p.o. szefa, od 1 grudnia 1952 r. do 29 lipca 1955 r. szef, a od 29 lipca 1955 r. do 15 grudnia 1956 r. sędzia Wydziału I Najwyższego Sądu Wojskowego. Z dniem 15 grudnia 1956 r. przeniesiony do rezerwy (szerzej zob. K. Szwagrzyk, Prawnicy czasu bezprawia..., s. 345). 
nia 1944 r., na godz. 16.00 czasu moskiewskiego, przy czym rozprawa miała się odbyć w siedzibie sądu, bez udziału prokuratora i obrońcy ${ }^{40}$. Postanowiono nie wzywać świadków, ponieważ oskarżony przyznał się do winy. Przewodniczący sądu ppłk Bronisław Rakowski na przewodniczącego rozprawy wyznaczył podchor. Juliusza Krupskiego, który miał orzekać przy udziale dwóch ławników, zarządził również o doprowadzeniu oskarżonego na rozprawę pod eskortą wojskową $^{41}$. 30 grudnia 1944 r. po przeprowadzeniu rozprawy, w której udział wzięli podchor. Juliusz Krupski jako przewodniczący, st. sierż. Cyryl Makowiecki i plut. Stefan Tynkiewicz jako ławnicy, szer. Jadwiga Grencewicz jako protokolant oraz Wacław Matejczyk jako oskarżony, sąd wydał wyrok, w którym uznał oskarżonego winnym popełnienia przestępstwa przeciwko obowiązkowi wojskowemu przewidzianemu w art. 117 § 2 KKWP, gdyż pomimo ciążącego na nim obowiązku w okresie od 9 września 1944 r. do 7 grudnia 1944 r. uchylał się od służby wojskowej i skazał go na karę 5 lat więzienia, przy czym na poczet kary zaliczył Matejczykowi okres aresztu tymczasowego, a jej odbywanie odroczył do chwili zakończenia działań wojennych. Matejczyka skierował do oddziału karnego, aby odbył tam służbę wojskową ${ }^{42}$.

21 kwietnia 1945 r. przed WSG rozpatrywano sprawę Michała Waśki i Grzegorza Paleckiego ${ }^{43}$, którzy zostali zatrzymani przez funkcjonariuszy bezpieczeństwa państwa, ponieważ wieczorem 25 lutego 1945 r. na drodze z Michałowa do Nowej Woli okradli z 4000 zł niejakiego Anatola Saka, wykorzystując fakt, że Sak był pod wpływem alkoholu ${ }^{44}$. W sporządzonym przez funkcjonariusza Posterunku MO w Michałowie 2 marca 1945 r. akcie oskarżenia wobec Waśki znalazła się adnotacja, że posiada on dokument, w którym rok urodzenia został zmieniony

${ }^{40}$ Udział prokuratora i obrońcy $\mathrm{w}$ rozprawie sądowej określały przepisy Dekretu z dnia 23 czerwca 1945 r. Kodeks Wojskowego Postępowania Karnego (Dz.U. z 1945 r. nr 36 poz. 216), zgodnie bowiem z art. $40 \S 2$ wskazanego Dekretu udział oskarżyciela publicznego w rozprawach oraz posiedzeniach niejawnych nie był obowiązkowy, zaś co się tyczy obrońcy, to jego udział regulował przepis art. 48 § 1 zgodnie, z którym oskarżonemu przysługiwało prawo korzystania z pomocy jednego obrońcy wojskowego, ponadto art. $53 \S 2$ określający szczegółowo sytuacje, kiedy udział obrońcy w rozprawie jest obowiązkowy oraz art. 54 zgodnie z którym, to kierownik sądu wyznaczał oskarżonemu obrońcę z urzędu w jednej instancji m.in. na prośbę oskarżonego lub z urzędu, jeżeli udział obrońcy jest w danej sprawie wskazany.

${ }^{41}$ AIPN Bi 212/3, Protokół posiedzenia niejawnego Wojskowego Sądu Garnizonowego w Białymstoku w sprawie o sygn. akt Kg 17/44 dotyczących Wacława Matejczyka, 28 XII 1944 r., k. 26-27.

${ }^{42}$ Ibidem, Wyrok Wojskowego Sądu Garnizonowego w Białymstoku z dnia 30 grudnia 1944 r. w sprawie o sygn. akt Kg 17/44 dotyczących Wacława Matejczyka, 30 XII 1944 r., k. 34-35.

${ }^{43}$ AIPN Bi 212/13, Protokół rozprawy Wojskowego Sądu Garnizonowego w sprawie o sygn. akt G 53/45 dotycząca Michała Waśko i Grzegorza Paleckiego, 21 IV 1945 r., k. 77-82.

${ }^{44}$ Ibidem, Protokół zeznań poszkodowanego Anatola Saka sporządzony przez funkcjonariusza Posterunku MO w Michałowie, 27 II 1945 r., k. 6-7. 
z 1921 na $1910^{45}$. Przesłuchującemu go 5 marca 1945 r. funkcjonariuszowi Powiatowej Komendy Milicji Obywatelskiej w Białymstoku zatrzymany zeznał:

Urodzony jestem w roku 1921, a paszport podrobiłem sam na 1910 po wkroczeniu wojsk radzieckich w 1944 roku. Uczyniłem to dlatego, ażebym nie został powołany do Wojska Polskiego. Ponieważ nie byłoby komu pracować na gospodarstwie ${ }^{46}$.

Sprawa trafiła do Wojskowej Prokuratury Garnizonowej w Białymstoku, gdzie 15 marca 1945 r. prokurator wydał postanowienie o wszczęciu postępowania karnego m.in. wobec Waśki z powodu naruszenia przepisu art. 9 Dekretu o ochronie Państwa i powierzył prowadzenie śledztwa oficerowi śledczemu Wojskowej Prokuratury Garnizonowej w Białymstoku ${ }^{47}$. W wyniku przeprowadzonego śledztwa por. Szadziewski 13 kwietnia 1945 r. w stosunku do Michała Waśki wydał postanowienie o pociągnięciu do odpowiedzialności karnej ${ }^{48}$, postanowienie o zastosowaniu aresztu tymczasowego i osadzeniu go w Więzieniu Karno-Śledczym w Białymstoku ${ }^{49}$ oraz postanowienie o uznaniu za dowód rzeczowy przerobionego przez Waśkę dokumentu tożsamości ${ }^{50}$. Następnego dnia oficer śledczy Wojskowej Prokuratury Garnizonowej w Białymstoku sporządził akt oskarżenia, w którym oskarżył Waśkę o przestępstwo z art. 9 Dekretu PKWN o ochronie Państwa („Kto w czasie wojny zabiera innej osobie cudze mienie, ruchome w celu przywłaszczenia, używając przemocy albo grożąc użyciem natychmiastowego gwałtu na osobie albo doprowadzając człowieka do stanu nieprzytomności lub bezbronności, podlega karze więzienia lub karze śmierci" ${ }^{51}$ ), art. 118 § $1 \mathrm{KKWP}$ w zW. z art. 117 $\S 1$ i 2 KKWP (uchylanie się od obowiązku służby wojskowej) oraz naruszenia art. $187 \mathrm{KK}$ („Kto w celu użycia za autentyczny podrabia lub przerabia dokument albo podrobionego lub przerobionego dokumentu za autentyczny używa, podlega karze więzienia do lat 5"52). W dniu sporządzenia aktu, tj. 14 kwietnia 1945 r.,

${ }^{45}$ Ibidem, Akt oskarżenia przeciwko Michałowi Waśko sporządzony przez funkcjonariusza Posterunku MO w Michałowie, 2 III 1945, k. 19.

${ }^{46}$ Ibidem, Protokół przesłuchania zatrzymanego Michała Waśko sporządzony przez funkcjonariusza Powiatowej Komendy MO w Białymstoku, 5 III 1945 r., k. 23.

${ }^{47}$ Ibidem, Postanowienie prokuratora Wojskowej Prokuratury Garnizonowej w Białymstoku o wszczęciu postępowania karnego w sprawie m.in. Michała Waśko, 15 III 1945 r., k. 30.

48 Ibidem, Postanowienie oficera śledczego Wojskowej Prokuratury Garnizonowej w Białymstoku o pociągnięciu do odpowiedzialności karnej Michała Waśko, 13 IV 1945 r., k. 44.

49 Ibidem, Postanowienie oficera śledczego Wojskowej Prokuratury Garnizonowej w Białymstoku o zastosowaniu środka zapobiegawczego w stosunku do Michała Waśko, 13 IV 1945 r., k. 45.

${ }^{50}$ Ibidem, Ibidem, Postanowienie oficera śledczego Wojskowej Prokuratury Garnizonowej w Białymstoku o uznaniu za dowód rzeczowy dowodu osobistego Michała Waśko, 13 IV 1945 r., k. 46.

${ }^{51}$ Dekret PKWN z dnia 30 października 1944 r. o ochronie Państwa, art. 9.

52 Rozporządzenie Prezydenta Rzeczypospolitej z dnia 11 lipca 1932 r., Kodeks karny, Dz.U. z 1932 r. nr 60 poz. 571, art. 187. 
został on zatwierdzony przez por. Władysława Oleckiego, prokuratora Wojskowej Prokuratury Garnizonowej w Białymstoku ${ }^{53} .18$ kwietnia 1945 r. odbyło się posiedzenie niejawne WSG, w którym udział wzięli por. Stanisław Tudruj jako przewodniczący oraz ppor. Hieronim Kowalski oraz ppor. Juliusz Krupski jako sędziowie, protokolant sierż. podchor. Edmund Dramowicz i podprokurator Wojskowej Prokuratury Garnizonowej w Białymstoku. Akt oskarżenia zatwierdzono, utrzymano w mocy areszt tymczasowy i na 21 kwietnia 1945 r. wyznaczono rozprawę, w której mieli uczestniczyć prokurator i obrońca. Podczas posiedzenia por. Stanisław Tudruj, będący zarazem szefem WSG, wyznaczył na przewodniczącego mającej się odbyć rozprawy ppor. Juliusza Krupskiego, zaś na obrońcę został naznaczony sierż. podchor. Mieczysław Szafranko ${ }^{54}$. Rozprawa odbyła się zgodnie z ustaleniami, w składzie sądowym zasiedli ppor. Juliusz Krupski jako przewodniczący oraz ławnicy - plut. Piotr Garczyński i plut. Robert Laus z 4 Zapasowego Pułku Piechoty, jednostki wojskowej stacjonującej w tym czasie w Białymstoku. Plut. podchor. Lucjan Szałaj pełnił rolę protokolanta, ppor. Stanisław Kondracki z Wojskowej Prokuratury Garnizonowej w Białymstoku oskarżyciela publicznego, a st. sierż. Zygmunt Jabłoński z 4 Zapasowego Pułku Piechoty występował w charakterze obrońcy. Michał Waśko w trakcie rozprawy przyznał się do uchylania się od służby wojskowej oraz do przerobienia dokumentu tożsamości ${ }^{55}$. WSG dokonał zmiany kwalifikacji prawnej czynu w zakresie zaboru mienia Anatolemu Sakowi, ponieważ uznał, że postępowanie oskarżonego wypełnia znamiona czynu określonego w art. 257 § $1 \mathrm{KK}-$ „Kto zabiera innej osobie cudze mienie ruchome w celu przywłaszczenia podlega karze więzienia do lat 5" 56 i w oparciu o art. 118 § 1 KKWP wydał wyrok, na mocy którego Waśko został skazany na karę 8 lat więzienia, przy czym jej wykonanie zostało odroczone do czasu zakończenia działań wojennych. Waśkę skierowano do oddziału karnego celem odbycia służby wojskowej. Nadto na poczet orzeczonej kary sąd zaliczył skazanemu okres tymczasowego aresztowania od 5 marca $1945 \mathrm{r}$. do 21 kwietnia 1945 r. $^{57}$

Kolejną sprawą związaną z uchylaniem się od obowiązku służby wojskowej była sprawa Michała Słysza. Został on zatrzymany przez funkcjonariuszy PUBP

53 AIPN Bi 212/13, Postanowienie w przedmiocie zatwierdzenia aktu oskarżenia i skierowania sprawy do sądu wydane przez prokuratora Wojskowej Prokuratury Garnizonowej w Białymstoku dotyczące m.in. Michała Waśko, 14 IV 1945 r., k. 60.

${ }^{54}$ Ibidem, Protokół posiedzenia niejawnego Wojskowego Sądu Garnizonowego w Białymstoku w sprawie o sygn. akt G. 53/45 dotyczącej m.in. Michała Waśko, 21 IV 1945 r., k. 62-63.

${ }_{55}$ Ibidem, Protokół rozprawy Wojskowego Sądu Garnizonowego w Białymstoku w sprawie o sygn. akt G. 53/45 dotyczącej m.in. Michała Waśko, 21 IV 1945 r., k. 77-82.

${ }_{56}$ Rozporządzenie Prezydenta Rzeczypospolitej z dnia 11 lipca 1932 r., Kodeks karny, art. 257.

${ }^{57}$ AIPN Bi 212/13, Wyrok Wojskowego Sądu Garnizonowego w Białymstoku w sprawie o sygn. akt G. 53/45 dotyczącej Michała Waśko, 21 IV 1945 r., k. 83-85. 
w Sokółce 23 kwietnia 1945 r. z powodu posiadania przerobionego dokumentu tożsamości, przy czym okazało się, że podlega obowiązkowi odbycia służby wojskowej $^{58}$. Podczas przesłuchania 27 kwietnia 1945 r. Słysz przyznał, że zmienił rok urodzenia w swoim dokumencie, ponieważ bał się odbywać służbę w Wojsku Polskim, z tego samego powodu nie stawił się przed Komisją Poborową w Sokół$\mathrm{ce}^{59} .28$ kwietnia 1945 r. sprawa została przekazana z PUBP w Sokółce do Wojskowej Prokuratury Garnizonowej w Białymstoku ${ }^{60} .14$ maja 1945 r. Słysz został osadzony w Więzieniu Karno-Śledczym w Białymstoku ${ }^{61}$. Jak wynika z materiałów archiwalnych, w jego sprawie 19 maja 1945 r. wydano aż pięć postanowień. Pierwsze wydał mjr Władysław Olecki - dotyczyło ono wszczęcia postępowania karnego z uwagi na naruszenia przez podejrzanego przepisów prawa określonych w art. 118 § 1 KKWP w zW. z art. 117 § 1 i 2 KKWP (uchylanie się od obowiązku służby wojskowej w czasie wojny) oraz naruszenia art. 187 KK. Olecki powierzył jednocześnie prowadzenie śledztwa w sprawie Michała Słysza oficerowi śledczemu Wojskowej Prokuratury Garnizonowej w Białymstoku por. Stanisławowi Kondrackiemu ${ }^{62}$. Ten ostatni wydał w tym samym dniu kolejne cztery postanowienia: o wszczęciu śledztwa z uwagi na trwałe uchylanie się od służby wojskowej i podrobienie w tym celu dowodu osobistego $0^{63}$, o zastosowaniu środka zapobiegawczego w postaci osadzenia Słysza w Więzieniu Karno-Śledczym w Białymstoku ${ }^{64}$, o uznaniu za dowód rzeczowy wydanego podejrzanemu przez władze niemieckie dowodu osobistego, w którym został przerobiony rok urodzenia ${ }^{65}$ oraz o pociągnięciu do odpowiedzialności karnej z uwagi na naruszenie przepisów z art. 118 § 1 KKWP w zW. z art. 117 § 1 i 2 KKW oraz art. $187 \mathrm{KK}$, ponieważ podejrzany od września $1944 \mathrm{r}$. aż do chwili zatrzymania 23 kwietnia 1945 r. trwale uchylał się od służby wojskowej i w tym celu dokonał przerobienia

${ }^{58}$ AIPN Bi 212/15, Akt zatrzymania sporządzony przez funkcjonariusza PUBP w Sokółce dotyczący Michała Słysza, 28 IV 1945 r., k. 3a.

${ }_{59}$ Ibidem, Protokół przesłuchania Michała Słysza przez funkcjonariusza PUBP w Sokółce w charakterze podejrzanego, 27 IV 1945 r., k. 5-6.

${ }^{60}$ Ibidem, Pismo Kierownika PUBP w Sokółce skierowane do Wojskowej Prokuratury Garnizonowej w Białymstoku dotyczące przekazania sprawy Michała Słysza, 28 IV 1945 r., k. 3.

${ }^{61}$ Ibidem, Pismo Naczelnika Więzienia Karno-Śledczego w Białymstoku do Wojskowej Prokuratury Garnizonowej w Białymstoku dotyczące osadzenia w więzieniu Michała Słysza, 15 V 1945 r., k. 7.

${ }^{62}$ Ibidem, Postanowienie prokuratora Wojskowej Prokuratury Garnizonowej w Białymstoku o wszczęciu postępowania karnego w sprawie Michała Słysza, 19 V 1945 r., k. 8.

${ }^{63}$ Ibidem, Postanowienie oficera śledczego Wojskowej Prokuratury Garnizonowej w Białymstoku o wszczęciu śledztwa w sprawie Michała Słysza, 19 V 1945 r., k. 9.

${ }^{64}$ Ibidem, Postanowienie oficera śledczego Wojskowej Prokuratury Garnizonowej w Białymstoku o zastosowaniu środka zapobiegawczego w stosunku do Michała Słysza, 19 V 1945 r., k. 10.

${ }^{65}$ Ibidem, Postanowienie oficera śledczego Wojskowej Prokuratury Garnizonowej w Białymstoku o uznaniu za dowód rzeczowy dowodu osobistego Michała Słysza, 19 V 1945 r., k. 11. 
zapisów w swoim dowodzie osobistym poprzez zmianę roku urodzenia z $1924 \mathrm{r}$. na 1925 r. ${ }^{66} \mathrm{~W}$ trakcie przesłuchania 19 maja 1945 r. Słysz zeznał:

Na swoje usprawiedliwienie podaję, że do wojska nie chciałem iść dlatego, że mam 7 ha gospodarki i oprócz mnie i 70-cio letniej [!] matki mojej nie ma nikogo więcej na niej - chciałem więc pozostać w domu i tę gospodarkę obrabiać ${ }^{67}$.

24 maja 1945 r. por. Stanisław Kondracki sporządził akt oskarżenia, w którym oskarżył Słysza o uchylanie się od obowiązku służby wojskowej i przerobienie $\mathrm{w}$ tym celu dokumentu tożsamości ${ }^{68}$. Akt oskarżenia jeszcze tego samego dnia został zatwierdzony przez prokuratora wojskowego mjr. Oleckiego ${ }^{69} .25$ maja 1945 r. akta sprawy zostały przekazane do $\mathrm{WSG}^{70}$, który następnego dnia odbył posiedzenie niejawne w składzie: kpt. Stanisław Tudruj (przewodniczący), por. Hieronim Kowalski ${ }^{71}$ i por. Juliusz Krupski (sędziowie), plut. podchor. Lucjan Szałaj (protokolant) oraz mjr Władysław Olecki (oskarżyciel publiczny). Zatwierdzono akt oskarżenia i utrzymano w mocy areszt tymczasowy wobec oskarżonego, a na 28 maja 1945 r. wyznaczono rozprawę, w której uczestniczyć miał prokurator oraz obrońca, natomiast oskarżony miał zostać na nią doprowadzony pod eskortą. Tudruj na przewodniczącego przyszłej rozprawy wyznaczył por. Hieronima Kowalskiego, na ławników st. sierż. Jarosława Dąbrowskiego i plut. Zdzisława Soroczyńskiego, natomiast na obrońcę ppor. Zygmunta Duckiego ${ }^{72}$. Rozprawa odbyła się zgodnie z planem, oprócz składu sądowego uczestniczyli w niej plut. podchor. Lucjan Szałaj jako protokolant, por. Jan Józefowicz - oficer śledczy Wojskowej Prokuratury Garnizonowej w Białymstoku, występujący w roli oskarżyciela publicznego, oraz oskarżony, który przyznał się do zarzuca-

${ }^{66}$ Ibidem, Postanowienie oficera śledczego Wojskowej Prokuratury Garnizonowej w Białymstoku o pociągnięciu do odpowiedzialności karnej Michała Słysza, 19 V 1945 r., k. 12.

${ }^{67}$ Ibidem, Protokół przesłuchania oskarżonego Michała Słysza przez oficera śledczego Wojskowej Prokuratury Garnizonowej w Białymstoku, 19 V 1945 r., k. 13-14.

${ }^{68}$ Ibidem, Akt oskarżenia w sprawie przeciwko Michałowi Słyszowi sporządzony przez oficera śledczego Wojskowej Prokuratury Garnizonowej w Białymstoku, 24 V 1945 r., k. 19.

${ }^{69}$ Ibidem, Postanowienie w przedmiocie zatwierdzenia aktu oskarżenia i skierowania sprawy do sądu wydane przez prokuratora Wojskowej Prokuratury Garnizonowej w Białymstoku dotyczące Michała Słysza, 24 V 1945 r., k. 21.

${ }^{70}$ Ibidem, Pismo prokuratora Wojskowej Prokuratury Garnizonowej w Białymstoku skierowane do Wojskowego Sądu Garnizonowego w Białymstoku dotyczące przekazania akt sprawy Michała Słysza, 25 V 1945 r., k. 22.

${ }^{71}$ Hieronim Kowalski s. Władysława ur. 30 IX 1910 r. w Tuchowie. W 1932 ukończył prawo na Uniwersytecie Jagiellońskim w Krakowie. Po studiach był sędzią Sądu Okręgowego w Rzeszowie. Od 29 X 1944 r. sędzia Wojskowego Sądu Garnizonowego w Białymstoku (szerzej zob. K. Szwagrzyk, Prawnicy czasu bezprawia..., s. 342).

${ }^{72}$ AIPN Bi 212/15, Protokół posiedzenia niejawnego Wojskowego Sądu Garnizonowego w Białymstoku w sprawie o sygn. akt G. 66/45 dotyczącej Michała Słysza, 26 V 1945 r., k. 30-31. 
nych mu czynów i do winy ${ }^{73}$. WSG wydał wyrok, na mocy którego Michał Słysz został skazany na karę 6 lat więzienia, przy czym jej wykonanie zostało odroczone do czasu zakończenia działań wojennych, a na poczet kary zaliczono skazanemu okres tymczasowego aresztowania od 23 kwietnia do 28 maja 1945 r., i skierowano Słysza do oddziału karnego celem odbycia służby wojskowej. W orzeczeniu czytamy również: „Wyrok niniejszy jest ostateczny i zaskarżeniu nie podlega"74. Na mocy Dekretu o amnestii z 2 sierpnia $1945 \mathrm{r}^{75}$ orzeczona względem Michała Słysza kara została darowana w całości ${ }^{76}$.

Podobny los spotkał Kazimierza Dowgierta oraz Pawła Radziwanowskiego, zatrzymanych również przez funkcjonariuszy PUBP w Sokółce. Dowgierta zatrzymano 16 kwietnia 1945 r. i, podobnie jak w przypadku Michała Słysza, okazało się, rok urodzenia w jego dowodzie tożsamości został zmieniony, a jego rocznik podlega obowiązkowej służbie wojskowej ${ }^{77}$. Z kolei Pawła Radziwanowskiego, który został zatrzymany 4 marca 1945 r. ${ }^{78}$, wcześniej, 11 września 1944 r., komisja poborowa uznała za zdolnego do służby wojskowej; miał zgłosić się do komisji w ciągu dwóch dni celem jej odbycia ${ }^{79}$. W trakcie przesłuchania 16 kwietnia 1945 r. Dowgiert thumaczył:

Dlatego nie chciałem pójść do wojska, bo jeden brat, tj. młodszy poszedł do wojska na Szkołę Podoficerską, a ojciec stary nie ma komu pracować, żałowałem ojca, bo ojciec cały czas, jak umarła matka, nie żenił się drugi raz i dlatego uważałem ojca. A po drugie nikt prawie nie poszedł do wojska, więc i ja nie chciałem pójść ${ }^{80}$.

Paweł Radziwanowski natomiast zeznał:

Dlatego się nie zgłosiłem, bo myślałem że tak się obejdzie ${ }^{81}$.

${ }^{73}$ Ibidem, Protokół rozprawy Wojskowego Sądu Garnizonowego w Białymstoku w sprawie o sygn. akt G. 66/45 dotyczącej Michała Słysza, 28 V 1945 r., k. 37-38.

${ }^{74}$ Ibidem, Wyrok Wojskowego Sądu Garnizonowego w Białymstoku w sprawie o sygn. akt G. 66/45 dotyczącej Michała Słysza, 28 V 1945 r., k. 42.

75 Dekret z dnia 2 sierpnia 1945 r. o amnestii, Dz. U. z 1945 r., nr 28 poz. 172.

${ }^{76}$ AIPN Bi 212/15, Postanowienie o zastosowaniu amnestii do skazanego Michała Słysza wydane przez Prokuratora Wojskowego Okręgu Warszawskiego, 24 VIII 1945 r., k. 47.

77 AIPN Bi 212/16, Akt zatrzymania Kazimierza Dowgierta sporządzony przez funkcjonariusza PUBP w Sokółce, 17 IV 1945 r., k. 3.

${ }^{78}$ AIPN Bi 212/17, Akt zatrzymania Pawła Radziwanowskiego sporządzony przez funkcjonariusza PUBP w Sokółce, 8 III 1945 r., k. 3.

${ }^{79}$ Ibidem, Pismo Przewodniczącego Komisji Poborowej skierowane do kierownika PUBP w Sokółce, 6 III 1945 r., k. 5.

${ }^{80}$ AIPN Bi 212/16, Protokół przesłuchania podejrzanego Kazimierza Dowgierta przez funkcjonariusza PUBP w Sokółce, 16 IV 1945 r., k. 6.

${ }^{81}$ AIPN Bi 212/17, Protokół przesłuchania podejrzanego Pawła Radziwanowskiego przez funkcjonariusza PUBP w Sokółce, 16 III 1945 r., k. 11. 
W obu przypadkach sprawa z PUBP w Sokółce trafiła do Wojskowej Prokuratury Garnizonowej w Białymstoku, gdzie 19 maja 1945 r. mjr Władysław Olecki wydał postanowienie o wszczęciu postępowania karnego, w przypadku Kazimierza Dowgierta w związku z naruszeniem przepisu art. 118 § 1 KKWP w zw. z art. 117 § 1 i 2 KKWP oraz art. $187 \mathrm{KK}^{82}$, tj. uchylanie się od służby wojskowej i przerobienie dokumentu tożsamości, zaś w przypadku Pawła Radziwanowskiego z uwagi na popełnienie czynu określonego w art. 118 § $1 \mathrm{KKWP}$ w zW. $\mathrm{z}$ art. $117 \S 1$ i 2 KKWP, tj. uchylanie się od służby wojskowej ${ }^{83}$. Na referenta obu spraw wyznaczono por. Stanisława Kondrackiego, który wydał w stosunku do Kazimierza Dowgierta (analogicznie jak w przypadku Michała Słysza) postanowienie o wszczęciu śledztwa, o zastosowaniu aresztu tymczasowego, o uznaniu przerobionego dokumentu za dowód rzeczowy oraz o pociągnięciu do odpowiedzialności karnej ${ }^{84}$, podobne ( $\mathrm{z}$ wyjątkiem postanowienia o uznaniu za dowód rzeczowy) postanowienia wydał co do Pawła Radziwanowskiego ${ }^{85} .22$ maja 1945 r. por. Kondracki przesłuchał obu oskarżonych, przy czym Dowgiert zmienił zeznania, mówiąc:

Ja Dowgiert Kazimierz nie przyznaję się do czynu i winy podrobienia w celu trwałego uchylania się od służby wojskowej mego dowodu osobistego („Personalausweisen”) przez przerobienie w nim daty urodzenia z „1921” na „1910”. Wyjaśniam, że datę urodzenia w tym dowodzie przerobiłem jeszcze na wiosnę 1944 r., wkrótce po otrzymaniu go od Amtskomisarza i zrobiłem to przeto, by uchronić się przed wywiezieniem mnie na roboty do Prus. (...) W czasie przesłuchania mnie w Sokółce w dn. 16 kwietnia rb byłem dość podpity, nie zdawałem sobie sprawy z tego co mówię i robię, i dlatego podpisałem protokół przesłuchania, w którym zostało zapisane moje zeznanie, że przeto podrobiłem dowód osob., by nie pójść do wojska ${ }^{86}$.

${ }^{82}$ AIPN Bi 212/16, Postanowienie Wojskowego Prokuratora Garnizonowego w Białymstoku o wszczęciu postępowania karnego w sprawie przeciwko Kazimierzowi Dowgiertowi, 19 V 1945 r., k. 7.

${ }^{83}$ AIPN Bi 212/17, Postanowienie Wojskowego Prokuratora Garnizonowego w Białymstoku o wszczęciu postępowania karnego w sprawie przeciwko Pawłowi Radziwanowskiemu, 19 V 1945 r., k. 12.

${ }^{84}$ AIPN Bi 212/16, Postanowienie o wszczęciu śledztwa w sprawie przeciwko Kazimierzowi Dowgiertowi, 19 V 1945 r., k. 8; Postanowienie o zastosowaniu środka zapobiegawczego w sprawie przeciwko Kazimierzowi Dowgiertowi, 19 V 1945 r., k. 9; Postanowienie o uznaniu za dowód rzeczowy w sprawie przeciwko Kazimierzowi Dowgiertowi, 19 V 1945 r., k. 10 oraz Postanowienie o pociągnięciu do odpowiedzialności karnej w sprawie przeciwko Kazimierzowi Dowgiertowi, 19 V 1945 r., k. 11.

${ }^{85}$ AIPN Bi 212/17, Postanowienie o wszczęciu śledztwa w sprawie przeciwko Pawłowi Radziwanowskiemu, 19 V 1945 r., k. 13; Postanowienie o zastosowaniu środka zapobiegawczego w sprawie przeciwko Pawłowi Radziwanowskiemu, 19 V 1945 r., k. 14 oraz Postanowienie o pociągnięciu do odpowiedzialności karnej w sprawie przeciwko Pawłowi Radziwanowskiemu, $19 \mathrm{~V}$ 1945 r., k. 15.

${ }^{86}$ AIPN Bi 212/16, Protokół przesłuchania oskarżonego Kazimierza Dowgierta przez oficera śledczego Wojskowej Prokuratury Garnizonowej w Białymstoku, 22 V 1945 r., k. 12-13. 
Następnego dnia po przesłuchaniu referent sporządził akt oskarżenia w sprawie przeciwko Radziwanowskiemu, któremu zarzucał popełnienie czynu z art. 118 $\S 1$ KKWP w zW. z art. 117 § 1 i 2 KKWP, ponieważ pomimo ciążącego na nim obowiązku oraz posiadając kartę powołania, od 13 września 1944 r. do dnia 3 marca 1945 r. nie zgłosił się do odbycia służby wojskowej ${ }^{87} .24$ maja 1945 r. spisano akt oskarżenia, w którym Kazimierz Dowgiert został oskarżony o uchylanie się od obowiązku służby wojskowej, tj. o naruszenie art. $118 \S 1$ KKWP W zw. z art. $117 \S 1$ i 2 KKWP oraz o przerobienie posiadanego przez siebie dokumentu tożsamości w celu trwałego uchylania się od służby wojskowej, tj. o dokonanie czynu z art. $187 \mathrm{KK}^{88}$. Oba akty oskarżenia zatwierdził mjr Olecki 24 maja $1945 \mathrm{r}^{89} 26$ maja 1945 r. odbyło się posiedzenie niejawne WSG w tym samym składzie, co w przypadku Michała Słysza, zarówno skład sędziowski, jak i szef sądu wydali prawie identyczne postanowienia odnośnie obu spraw (z tym wyjątkiem, że na przewodniczącego rozprawy zaplanowanej na 28 maja 1945 r. wyznaczono por. Juliusza Krupskiego) ${ }^{90}$. Dowgiert i Radziwanowski przyznali się do popełnienia zarzucanych im czynów, przy czym Dowgiert zaprzeczał, jakoby sfałszował dokument tożsamości w celu uchylenia się od służby wojskowej ${ }^{91}$. Po przeprowadzeniu rozprawy, w której oskarżycielem publicznym był por. Kondracki, a protokolantem sierż. podchor. Edmund Dramowicz, sąd skazał każdego z oskarżonych na karę 5 lat więzienia, odraczając przy tym jej wykonanie do chwili zakończenia działań wojennych. Na poczet orzeczonej kary zaliczył każdemu ze skazanych okres aresztu tymczasowego oraz celem odbycia służby wojskowej

87 AIPN Bi 212/17, Akt oskarżenia w sprawie przeciwko Pawłowi Radziwanowskiemu sporządzony przez oficera śledczego Wojskowej Prokuratury Garnizonowej w Białymstoku, 23 V 1945 r., k. 19-20.

${ }^{88}$ AIPN Bi 212/16, Akt oskarżenia w sprawie przeciwko Kazimierzowi Dowgiertowi sporządzony przez oficera śledczego Wojskowej Prokuratury Garnizonowej w Białymstoku, 24 V 1945 r., k. 18-19.

${ }^{89}$ Ibidem, Postanowienie w przedmiocie zatwierdzenia aktu oskarżenia i skierowania sprawy do sądu wydane przez prokuratora Wojskowej Prokuratury Garnizonowej w Białymstoku dotyczące Kazimierza Dowgierta, 24 V 1945 r., k. 20; AIPN Bi 212/17, Postanowienie w przedmiocie zatwierdzenia aktu oskarżenia i skierowania sprawy do sądu wydane przez prokuratora Wojskowej Prokuratury Garnizonowej w Białymstoku dotyczące Pawła Radziwanowskiego, 24 V 1945 r., k. 21.

${ }^{90}$ AIPN Bi 212/16, Protokół posiedzenia niejawnego Wojskowego Sądu Garnizonowego w Białymstoku w sprawie o sygn. akt G. 67/45 dotyczącej Kazimierza Dowgierta, 26 V 1945 r., k. 24-25; AIPN Bi 212/17, Protokół posiedzenia niejawnego Wojskowego Sądu Garnizonowego w Białymstoku w sprawie o sygn. akt G. 68/45 dotyczącej Pawła Radziwanowskiego, 26 V 1945 r., k. 23-24.

${ }^{91}$ AIPN Bi 212/16, Protokół rozprawy Wojskowego Sądu Garnizonowego w Białymstoku w sprawie o sygn. akt G. 67/45 dotyczącej Kazimierza Dowgierta, 28 V 1945 r., k. 29; AIPN Bi 212/17, Protokół rozprawy Wojskowego Sądu Garnizonowego w Białymstoku w sprawie o sygn. akt G. 68/45 dotyczącej Pawła Radziwanowskiego, 28 V 1945 r., k. 28. 
skierował ich do oddziału karnego ${ }^{92}$. Podobnie, jak w przypadku Michała Słysza, obydwu skazanym kara została darowana w całości na mocy Dekretu o amnestii z dnia 2 sierpnia 1945 r., zostali także zwolnieni z odbywania służby wojskowej w oddziale karnym ${ }^{93}$.

15 maja 1945 r. PUBP w Sokółce zatrzymał Kazimierza Kochanowicza. Powodem był podrobiony dokument tożsamości oraz to, że zatrzymany podlegał obowiązkowi służby wojskowej ${ }^{94}$. Kochanowicz zeznał, że paszport został podrobiony przez jego znajomego, który również przerobił swój dokument tożsamości wpisując w nim jako rok urodzenia 1926, ponieważ w przypadku poboru do wojska jako rówieśnicy mieli odbywać służbę wojskową razem ${ }^{95} .25$ maja 1945 r. sprawa Kochanowicza była już rozpoznawana w Wojskowej Prokuraturze Garnizonowej w Białymstoku; mjr Olecki wydał postanowienie o wszczęciu postępowania karnego i powierzeniu prowadzenia śledztwa por. Januszowi Kobylińskiemu, oficerowi śledczemu Wojskowej Prokuratury Garnizonowej w Białymstoku ${ }^{96}$. Referent wydał w tej sprawie kolejne postanowienia: 26 maja 1945 r. postanowienie o zastosowaniu środka zapobiegawczego polegającego na osadzeniu zatrzymanego w Więzieniu Karno-Śledczym w Białymstoku ${ }^{97}$, a 28 maja 1945 r. - postanowienie o pociągnięciu do odpowiedzialności karnej ${ }^{98}$. W aktach sprawy znajduje się protokół przesłuchania Kochanowicza datowany na 28 maja 1945 r., w którym oskarżony relacjonuje przebieg zatrzymania przez funkcjonariuszy, wspominając o zaborze mienia, m.in. pieniędzy i pasów skórzanych, oraz stosowaniu wobec niego siły fizycznej (kopianie i bicie aż do krwi przy użyciu karabinu, kamienia

${ }^{2}$ AIPN Bi 212/16, Wyrok Wojskowego Sądu Garnizonowego w Białymstoku w sprawie o sygn. akt G. 67/45 dotyczącej Kazimierza Dowgierta, 28 V 1945 r., k. 33; AIPN Bi 212/17, Wyrok Wojskowego Sądu Garnizonowego w Białymstoku w sprawie o sygn. akt G. 68/45 dotyczącej Pawła Radziwanowskiego, 28 V 1945 r., k. 32.

${ }^{3}$ AIPN Bi 212/16, Postanowienie o zastosowaniu amnestii w stosunku do skazanego Kazimierza Dowgierta wydane przez prokuratora Wojskowego Okręgu Warszawskiego, 24 VIII 1945 r., k. 38; AIP Bi 212/17, Postanowienie o zastosowaniu amnestii w stosunku do skazanego Pawła Radziwanowskiego wydane przez prokuratora Wojskowego Okręgu Warszawskiego, 24 VIII 1945 r., k. 37.

${ }^{44}$ AIPN Bi 212/18, Akt zatrzymania Kazimierza Kochanowicza sporządzony przez funkcjonariusza PUBP w Sokółce, 17 V 1945 r., k. 4.

${ }_{95}$ Ibidem, Protokół przesłuchania podejrzanego Kazimierza Kochanowicza przez funkcjonariusza PUBP w Sokółce, 15 V 1945 r., k. 7.

${ }^{96}$ Ibidem, Postanowienie prokuratora Wojskowej Prokuratury Garnizonowej w Białymstoku o wszczęciu postępowania karnego w sprawie przeciwko Kazimierzowi Kochanowiczowi, 25 V 1945 r., k. 10.

${ }^{97}$ Ibidem, Postanowienie o zastosowaniu środka zapobiegawczego w sprawie przeciwko Kazimierzowi Kochanowiczowi, 26 V 1945 r., k. 14.

${ }_{98}$ Ibidem, Postanowienie o pociągnięciu do odpowiedzialności karnej Kazimierza Kochanowicza wydane przez oficera śledczego Wojskowej Prokuratury Garnizonowej w Białymstoku, 28 V 1945 r., k. 15. 
i sprzączek). Kochanowicz zeznał, że także jego siostra była przez funkcjonariuszy bita karabinem, oraz że została ponadto pobita osoba postronna, która była świadkiem zatrzymania ${ }^{99}$. Uwierzytelniony odpis tego protokołu został przekazany Wojskowemu Prokuratorowi Garnizonowemu w Białymstoku, w aktach brakuje natomiast jakiejkolwiek informacji o dalszym wyjaśnianiu tej sprawy ${ }^{100}$. W akcie oskarżenia sporządzonym 29 maja 1945 r. przez chor. Janusza Kobylińskiego Kochanowiczowi zarzucono, że od września 1944 r. do 15 maja 1945 r. nie stawił się do odbycia służby wojskowej, mimo że był do tego zobowiązany, czym naruszył art. 118 § 1 KKWP w związku z art. 117 § 1 i 2 KKWP, a także iż w lutym 1945 r. dwukrotnie posłużył się dokumentem tożsamości z wpisaną do niego nieprawdziwą datą urodzenia, tj. popełnił przestępstwo przewidziane $\mathrm{w}$ art. $193 \mathrm{KK}^{101}$ („Kto wyłudza poświadczenie nieprawdy przez podstępne wprowadzenie w błąd urzędnika lub osoby publicznego zaufania, albo kto takiego świadectwa używa, podlega karze więzienia do lat 2 lub aresztu do lat 2"102). Tego samego dnia akt oskarżenia, po zatwierdzeniu przez mjr. Oleckiego, przekazano do $\mathrm{WSG}^{103}$. 1 czerwca 1945 r. odbyło się posiedzenie niejawne WSG (przewodniczący - kpt. Stanisław Tudruj, sędziowie - por. Hieronim Kowalski i por. Juliusz Krupski, oskarżyciel publiczny prokurator mjr Władysław Olecki i protokolant chor. Jadwiga Grencewicz). Po zatwierdzeniu aktu oskarżenia i utrzymaniu aresztu tymczasowego wyznaczono termin rozprawy na 4 czerwca 1945 r., przewodniczyć jej miał por. Hieronim Kowalski ${ }^{104}$. Kochanowicz przyznał się do winy ${ }^{105}$, a WSG (por. Hieronim Kowalski jako przewodniczący, sierż. Jarosław Dąbrowski i plut. Józef Piszczałowski jako ławnicy, z udziałem plut. podchor. Lucjana Szałaja jako protokolanta, w obecności oskarżyciela publicznego chor. Janusza Kobylińskiego

99 Ibidem, Protokół przesłuchania oskarżonego Kazimierza Kochanowicza przez oficera śledczego Wojskowej Prokuratury Garnizonowej w Białymstoku, 28 V 1945 r., k. 16-17.

${ }^{100}$ Ibidem, Postanowienie o uzupełniającym zeznaniu w sprawie Kazimierza Kochanowicza wydane przez oficera śledczego Wojskowej Prokuratury Garnizonowej w Białymstoku, 29 V 1945 r., k. 20.

${ }^{101}$ Ibidem, Akt oskarżenia w sprawie przeciwko Kazimierzowi Kochanowiczowi sporządzony przez oficera śledczego Wojskowej Prokuratury Garnizonowej w Białymstoku, 29 V 1945 r., k. 22.

102 Rozporządzenie Prezydenta Rzeczypospolitej z dnia 11 lipca 1932 r., Kodeks Karny, art. 193.

103 AIPN Bi 212/18, Postanowienie w przedmiocie zatwierdzenia aktu oskarżenia i skierowaniu sprawy do sądu dotyczące Kazimierza Kochanowicza wydane przez prokuratora Wojskowej Prokuratury Garnizonowej w Białymstoku, 29 V 1945 r., k. 23; Pismo Prokuratora Wojskowej Prokuratury Garnizonowej w Białymstoku skierowane do Wojskowego Sądu Garnizonowego w Białymstoku przesyłającego akta sprawy Kazimierza Kochanowicza, 29 V 1945 r., k. 24.

104 Ibidem, Protokół posiedzenia niejawnego Wojskowego Sądu Garnizonowego w Białymstoku w sprawie o sygn. akt G. 70/45 dotyczącej Kazimierza Kochanowicza, 1 VI 1945 r., k. 25-26.

${ }^{105}$ Ibidem, Protokół rozprawy głównej przed Wojskowym Sądem Garnizonowym w Białymstoku w sprawie o sygn. akt G. 70/45 dotyczącej Kazimierza Kochanowicza, 4 VI 1945 r., k. 32-33. 
i podpor. Zygmunta Duckiego - obrońcy) wydał wyrok. Kochanowicza skazano na na karę 5 lat więzienia, z odroczeniem jej wykonania do czasu zakończenia działań wojennych, przy czym zaliczono skazanemu okres aresztu tymczasowego na poczet orzeczonej kary. Sąd skierował go do oddziału karnego w celu odbycia służby wojskowej. Orzeczona kara zgodnie z treścią wyroku była ostateczna i nie podlegała zaskarżeniu ${ }^{106}$.

Kolejna sprawa tego typu dotyczyła Stanisława Bruszewskiego, zatrzymanego 2 listopada 1945 r. przez grupę operacyjną KWMO w Białymstoku w gajówce Gaj około $2 \mathrm{~km}$ od Knyszyna, w związku z prowadzonymi tam przez funkcjonariuszy organów bezpieczeństwa państwa działaniami operacyjnymi ${ }^{107}$. Ustalono, że Bruszewski popełnił przestępstwo określone w art. 117 § 2 KKWP (mimo obowiązku nie zgłosił się do odbycia służby wojskowej) ${ }^{108}$. Tego samego dnia Jerzy Suralski ${ }^{109}$, st. oficer śledczy PUBP w Białymstoku, wydał postanowienie o pociągnięciu go do odpowiedzialności karnej ${ }^{110}$. W trakcie przesłuchania 20 listopada 1945 r. podejrzany mówił:

Przyznaję się, iż jako rocznik 1925 powinienem zarejestrować się w R.K.U. Przyznaję się, iż wiedziałem o powołaniu do Wojska i rejestrowaniu się w R.K.U. Nie rejestrowałem się w R.K.U. jako rocznik 1925 podlegający rejestracji w R.K.U., gdyż miałem gospodarstwo rolne i musiałem na nim pracować ${ }^{111}$.

Następnego dnia Suralski sporządził akt oskarżenia, w którym zarzucał Bruszewskiemu popełnienie przestępstwa $\mathrm{z}$ art. 118 § $1 \mathrm{w} \mathrm{zW} . \mathrm{z}$ art. 117 § $2 \mathrm{KKWP}$. Akt ten został zatwierdzony tego samego dnia przez kierownika PUBP w Białymstoku ${ }^{112}$, a następnie przesłany do Wojskowej Prokuratury Garnizonowej w Białymstoku, gdzie 23 listopada 1945 r. zatwierdził go mjr Władysław Ole-

${ }^{106}$ Ibidem, Wyrok Wojskowego Sądu Garnizonowego w Białymstoku w sprawie o sygn. akt G. 70/45 dotyczącej Kazimierza Kochanowicza, 4 VI 1945 r., k. 36-37.

107 AIPN Bi 212/211, Sprawozdanie funkcjonariusza KWMO w Białymstoku dotyczące działań operacyjnych grupy operacyjnej KWMO w Białymstoku w okolicach miasta Knyszyn, 3 XI 1945 r., k. 1.

${ }^{108}$ Ibidem, Postanowienie o wszczęciu śledztwa w sprawie Stanisława Bruszewskiego, 5 XI 1945 r., k. 4.

109 Stanisław Bruszewski s. Tobiasza, ur. 15 III 1910 r. w Suwałkach, funkcjonariusz organów bezpieczeństwa państwa, przebieg służby dostępny na stronie elektronicznej BIP Instytutu Pamięci Narodowej w zakładce Katalogi Biura Lustracyjnego, https://katalog.bip.ipn.gov.pl/informacje/62856 [dostęp: 09.10.2019].

110 AIPN Bi 212/211, Postanowienie o pociągnięciu do odpowiedzialności karnej Stanisława Bruszewskiego wydane przez st. oficera śledczego PUBP w Białymstoku, 5 XI 1945 r., k. 5.

111 Ibidem, Protokół przesłuchania oskarżonego Stanisława Bruszewskiego przez funkcjonariusza PUBP w Białymstoku, 20 XI 1945 r., k. 8-8v.

112 Ibidem, Akt oskarżenia w sprawie przeciwko Stanisławowi Bruszewskiemu sporządzony przez oficera śledczego PUBP w Białymstoku, 21 XI 1945 r., k. 11. 
cki i skierował sprawę do $\mathrm{WSG}^{113}$. Rozprawa sądowa odbyła się 28 listopada 1945 r., wzięli w niej udział por. Julian Krupski jako przewodniczący, mjr Józef Popowski ${ }^{114}$ i por. Hieronim Kowalski jako sędziowie, a przebieg rozprawy protokołowała chor. Jadwiga Grencewicz. Na rozpoznanie sprawy nie stawił się oskarżyciel publiczny, przybył natomiast obrońca - chor. Jan Fedyk z Rejonowej Komisji Uzupełnień w Białymstoku. Oskarżony przyznał się do winy i złożył wyjaśnienia:

Mając liczną rodzinę bez środków do życia, po spaleniu przez Niemców naszych zabudowań, chciałem zabezpieczyć byt swej rodziny i chociaż były ogłoszenia o rejestracji do wojska rocznika 1925, na wezwanie nie zgłosiłem się i nie poszedłem do R.K.U mając zamiar, że gdy tylko zabezpieczę jako tako swoją rodzinę zgłosić się do R.K.U. Nie zdawałem sobie sprawy, jako człowiek obywatelsko mało uświadomiony, że wskutek niezgłoszenia się do rejestracji, popełniam przestępstwo i narażam się na odpowiedzialność karnąa15.

Bruszewskiego uznano winnym dhuższego uchylania się od obowiązku wojskowego (art. 118 § 1 w zw. z art. 117 § 1 i 2 KKWP) i skazano na karę roku więzienia, zaś na poczet orzeczonej kary pozbawienia wolności zaliczono skazanemu okres tymczasowego aresztu od 2 do 28 listopada 1945 r. ${ }^{116}$

W listopadzie 1945 r. WSG rozpatrywał również sprawę Stefana Kajki. 15 listopada 1945 r. wszczęto przeciw niemu śledztwo w związku z podejrzeniem o przynależność do AK, posiadanie broni bez wymaganego prawem zezwolenia, jak również uchylanie się od obowiązku służby wojskowej, tj. o naruszenie przepisów z art. 1 i art. 4 § 1 lit a Dekretu PKWN z 30 października 1944 r. o ochronie

113 Ibidem, Postanowienie w przedmiocie zatwierdzenia aktu oskarżenia w sprawie przeciwko Stanisławowi Bruszewskiemu i skierowaniu sprawy do sądu wydane przez prokuratora Wojskowej Prokuratury Garnizonowej w Białymstoku, 23 XI 1945 r., k. 12.

114 Józef Popowski s. Franciszka ur. 1 listopada 1895 r. w Supraślu. W 1916 ukończył Instytut Prawniczy w Piotrogrodzie. W latach 1924-1936 wykonywał zawód notariusza w Białymstoku. W okresie od 2 lipca 1945 r. do 18 lutego 1946 r. sędzia Wojskowego Sądu Garnizonowego w Białymstoku, a od 19 lutego 1946 r. do 11 sierpnia 1947 r. zastępca szefa Wojskowego Sądu Rejonowego w Białymstoku. Od 12 sierpnia 1947 r. do 8 stycznia 1948 r. zastępca szefa Wojskowego Sądu Okręgowego nr IV we Wrocławiu, a od 9 stycznia 1948 r. do 3 sierpnia 1948 r. zastępca szefa Wojskowego Sądu Rejonowego w Bydgoszczy. Z dniem 3 sierpnia 1948 r. na własną prośbę zwolniony z wojska, niedługo po tym aresztowany i skazany wyrokiem Wojskowego Sądu Okręgowego nr I w Warszawie z 17 maja 1949 r. na karę 3 lat więzienia za przyjmowanie korzyści majątkowych od rodzin osób skazanych przez Wojskowy Sąd Rejonowy w Białymstoku (szerzej zob. K. Szwagrzyk, Prawnicy czasu bezprawia..., s. 405).

115 AIPN Bi 212/211, Protokół rozprawy Wojskowego Sądu Garnizonowego w Białymstoku w sprawie o sygn. akt G. 481/45 dotyczącej Stanisława Bruszewskiego, 28 XI 1945 r., k. 15v.

${ }_{116}$ Ibidem, Wyrok Wojskowego Sądu Garnizonowego w Białymstoku w sprawie o sygn. akt G. 481/45 dotyczącej Stanisława Bruszewskiego, 28 XI 1945 r., k. 17-17v. 
Państwa oraz art. $117 \S 2 \mathrm{KKWP}^{117}$. Wydano także postanowienie o zastosowaniu wobec podejrzanego aresztu tymczasowego ${ }^{118}$. W trakcie przesłuchania 15 listopada 1945 r. Kajko wskazał powody, dla których nie zgłosił się do odbycia służby wojskowej:

Nie, ja się nie zgłosiłem do rejestracji w R.K.U., gdyż z Niemiec wróciłem w miesiącu maju, i nie wiedziałem że mam się zgłosić do R.K.U ${ }^{119}$.

16 listopada 1945 r. Stefan Kajko został pociągnięty do odpowiedzialności karnej ${ }^{120} .18$ listopada 1945 r. Eliasz Trokenheim ${ }^{121}$, oficer śledczy PUBP w Łomży sporządził akt oskarżenia, w którym Kajko został oskarżony m.in. o to, że po wyzwoleniu spod okupacji niemieckiej w 1945 r. jako mężczyzna z rocznika podlegającego poborowi do wojska (1922 r.) nie stawił się do odbycia służby. Tego samego dnia akt oskarżenia zatwierdził kierownik PUBP w Łomży ${ }^{122}$ a 1 grudnia - mjr Władysław Olecki, prokurator Wojskowej Prokuratury Garnizonowej w Białymstoku, przy czym w zakresie kwalifikacji czynu wskazał, że zachowanie Kajki wyczerpuje znamiona czynu określone w art. 118 § $1 \mathrm{w}$ zW. z art. 117 § 1 i 2 KKWP, a nie tylko art. 117 § $2 \mathrm{KKWP}^{123} .13$ grudnia $1945 \mathrm{r}$. odbyła się rozprawa sądowa, protokołowana przez chor. Jadwigę Grancewicz, w której udział wziął mjr Józef Popowski jako przewodniczący składu sędziowskiego, por. Juliusz Krupski jako sędzia oraz chor. Stanisław Rębacz z MO jako ławnik. W rozprawie uczestniczył także ppor. Juliusz Kessler, wiceprokurator Wojskowej Prokuratury Garnizonowej w Białymstoku w roli oskarżyciela publicznego oraz chor. Adam Kaleta z Rejonowej Komisji Uzupełnień w Białymstoku jako obrońca. W trakcie rozprawy Kajko przyznał się do winy. Wyjaśniał:

${ }^{117}$ AIPN Bi 212/233, Postanowienie o wszczęcie śledztwa wydane przez oficera śledczego PUBP w Łomży wobec Stefana Kajko, 15 XI 1945 r., k. 1.

118 Ibidem, Postanowienie o zastosowaniu wobec Stefana Kajko aresztu tymczasowego wydane przez oficera śledczego PUBP w Łomży, 15 XI 1945 r., k. 2.

119 Ibidem, Protokół przesłuchania podejrzanego Stefana Kajko przez oficera śledczego PUBP w Łomży, 15 XI 1945 r., k. 7.

${ }^{120}$ Ibidem, Postanowienie o pociągnięciu do odpowiedzialności karnej Stefana Kajko wydane przez oficera śledczego PUBP w Łomży, 16 XI 1945 r., k. 8.

${ }^{121}$ Eliasz Trokenheim s. Szmula, ur. 12 maja 1920 r. w Warszawie, funkcjonariusz organów bezpieczeństwa państwa, przebieg służby dostępny na stronie elektronicznej BIP Instytutu Pamięci Narodowej w zakładce Katalogi Biura Lustracyjnego, https://katalog.bip.ipn.gov.pl/informacje/61790 [dostęp: 11.10.2019].

122 AIPN Bi 212/233, Akt oskarżenia w sprawie przeciwko Stefanowi Kajko sporządzony przez oficera śledczego PUBP w Łomży, 18 XI 1945 r., k. 13.

${ }^{123}$ Ibidem, Postanowienie o przedmiocie zatwierdzenia aktu oskarżenia wydane przez mjr. Władysława Oleckiego - Prokuratora Wojskowej Prokuratury Garnizonowej w Białymstoku, 1 XII 1945 r., k. 15. 
Po powrocie z Niemiec w maju 1945 r. dlatego nie rejestrowałem się w R.K.U. chociaż mój rocznik podlegał mobilizacji, gdyż nic mi o tem nie było wiadome, bo żadnych ogłoszeń nie czytałem i żadnego imiennego wezwania nie otrzymałem ${ }^{124}$.

Na mocy art. 8 § 1 i 2 Dekretu o amnestii z 2 sierpnia 1945 r. ${ }^{125}$ na wniosek oskarżyciela publicznego WSG umorzył postępowanie karne wobec Kajki co do popełnienia przestępstwa określonego w art. 1 i art. 4 § 1 lit. a Dekretu PKWN z 30 października 1944 r. o ochronie Państwa ${ }^{126}$, natomiast za uchylanie się od służby wojskowej skazał oskarżonego na karę roku więzienia, zaliczając mu na poczet kary okres tymczasowego aresztowania od 14 listopada do 13 grudnia 1945 r. ${ }^{127}$

Uchylanie się od obowiązku służby wojskowej było rozpatrywane przez WSG w 1945 r. również łącznie z przynależnością oskarżonych do AK, wówczas to sądzeni ponosili odpowiedzialność karną zarówno z art. 118 § $1 \mathrm{KKWP}$ w związku z art. 117 § 1 i 2 KKWP, jak i z przepisów Dekretu PKWN z 30 października 1944 r. o ochronie Państwa. Niniejsza analiza obejmuje cztery przypadki spraw prowadzonych przez PUBP lub WUPB w Białymstoku: sprawę Antoniego Gistarowicza, zatrzymanego 10 lipca 1945 r., Justyna Seweruka, zatrzymanego 8 maja 1945 r. oraz Jana Jóźwickiego i Franciszka Paca, zatrzymanych 8 sierpnia 1945 r. Każdy z wymienionych podczas śledztwa prowadzonego przez PUBP w Białymstoku był przesłuchiwany kilka razy. 10 sierpnia 1945 r. Antoni Gistarowicz na pytanie funkcjonariusza o przyczyny uchylania się od obowiązku służby wojskowej zeznat:

Ja dlatego uchylałem się od służby wojskowej, że widząc, że inni nie stawiają się do R.K.U. ja też poszedłem za ich przykładem ${ }^{128}$.

Gisztarowicz przyznał się jednocześnie do przynależności do AK, co potwierdził także w trakcie kolejnego przesłuchania, 15 sierpnia 1945 r.; zeznał wówczas, że od służby wojskowej uchylał się świadomie i z własnej woli ${ }^{129}$. Prowadzone przez PUBP w Białymstoku śledztwo zakończyło się 15 sierpnia 1945 r. sporządzeniem

${ }^{124}$ Ibidem, Protokół rozprawy Wojskowego Sądu Garnizonowego w Białymstoku w sprawie o sygn. akt G. 505/45 dotyczącej Stefana Kajko, 13 XII 1945 r., k. 18v.

${ }_{125}$ Dekret z dnia 2 sierpnia 1945 r. o amnestii, art. 8.

126 AIPN Bi 212/233, Protokół rozprawy Wojskowego Sądu Garnizonowego w Białymstoku w sprawie o sygn. akt G. 505/45 dotyczącej Stefana Kajko, 13 XII 1945 r., k. 18-19.

127 Ibidem, Wyrok Wojskowego Sądu Garnizonowego w Białymstoku w sprawie o sygn. akt G 505/45 dotyczącej Stefana Kajko, 13 XII 1945 r. k. 20-21.

128 AIP Bi 212/49, Protokół przesłuchania Antoniego Gisztarowicza w charakterze podejrzanego przez funkcjonariusza PUBP w Białymstoku, 10 VIII 1945 r., k. 3.

129 Ibidem, Protokół przesłuchania Antoniego Gisztarowicza w charakterze podejrzanego przez funkcjonariusza PUBP w Białymstoku, 15 VIII 1945 r., k. 8-8v. 
aktu oskarżenia przez oficera śledczego Mariana Kutyłowskiego ${ }^{130}$. Giesztarowiczowi zarzucono, że od 27 lipca 1944 r. do chwili sporządzenia aktu oskarżenia uchylał się od obowiązku służby wojskowej, tj. popełnił przestępstwo z art. 118 $\S 1$ KKWP w związku z art. 117 § 1 i 2 KKWP, a ponadto od kwietnia 1945 r. należał do nielegalnej organizacji AK, czym dopuścił się przestępstwa określonego w art. 1 Dekretu PKWN z 30 października 1944 r. o ochronie Państwa ${ }^{131}$ („Kto zakłada związek, mający na celu obalenie demokratycznego ustroju Państwa Polskiego, albo kto w takim związku bierze udział, kieruje nim, dostarcza mu broni lub udziela mu innej pomocy, podlega karze więzienia lub karze śmierci") ${ }^{132}$. Giesztarowiczowi zarzucano też, że od maja 1945 r. bez wymaganego zezwolenia posiadał broń i amunicję, popełniając tym samym przestępstwo z art. $4 \S 1$ lit a Dekretu PKWN o ochronie Państwa ${ }^{133}$ („Kto w czasie wojny: bez prawnego zezwolenia władzy wyrabia, przechowuje, nabywa lub zbywa broń, amunicję, materiał lub przyrząd wybuchowy albo inny przedmiot, mogący sprowadzić niebezpieczeństwo powszechne, podlega karze więzienia albo karze śmierci"134). Akt oskarżenia zatwierdził mjr Olecki i przekazał wraz z aktami sprawy zgodnie z właściwością do $\mathrm{WSG}^{135} .27$ sierpnia $1945 \mathrm{r}$. odbyło się posiedzenie niejawne WSG, któremu przewodniczył kpt. Stanisław Turduj, ponadto obecni byli sędziowie kpt. Józef Popowski i por. Juliusz Krupski oraz protokolant plut. Joachim Kaczanowski i oskarżyciel publiczny mjr Władysław Olecki. Zatwierdzono akt oskarżenia, utrzymano w mocy areszt tymczasowy i na 31 sierpnia 1945 r. wyznaczono rozprawę, która miała się odbyć w lokalu sądu, bez udziału prokuratora i obrońcy (z uwagi na „interes państwa”); zdecydowano też o doprowadzeniu na rozprawę oskarżonego przybywającego w Więzieniu Karno-Śledczym w Białymstoku. Kpt. Tudruj przydzielił tę sprawę do własnego referatu ${ }^{136}$. Podczas rozprawy Gisztarowicz przyznał się jedynie do uchylania się od służby wojskowej

130 Marian Konstanty Kutyłowski s. Ignacego, ur. 10 X 1916 r. w Kostrach-Starych, funkcjonariusz organów bezpieczeństwa państwa, przebieg służby dostępny na stronie elektronicznej BIP Instytutu Pamięci Narodowej w zakładce Katalogi Biura Lustracyjnego, https://katalog.bip.ipn.gov. pl/informacje/13934 [dostęp: 07.06.2019].

131 AIP Bi 212/49, Akt oskarżenia w sprawie przeciwko Antoniemu Gistarowiczowi sporządzony przez oficera śledczego PUBP w Białymstoku, 15 VIII 1945 r., k. 11-12.

132 Dekret PKWN z dnia 30 października 1944 r. o ochronie Państwa, art. 1.

133 AIPN Bi 212/49, Akt oskarżenia w sprawie przeciwko Antoniemu Gistarowiczowi sporządzony przez oficera śledczego PUBP w Białymstoku, 15 VIII 1945 r., k. 11-12.

${ }_{134}$ Dekret PKWN z dnia 30 października 1944 r. o ochronie Państwa, art. 4 § 1 lit. a.

135 AIPN Bi 212/49, Postanowienie w przedmiocie zatwierdzenia aktu oskarżenia w sprawie przeciwko Antoniemu Gistarowiczowi i skierowaniu sprawy do sądu wydane przez prokuratora Wojskowej Prokuratury Garnizonowej w Białymstoku, 24 VIII 1945 r., k. 13.

${ }^{136}$ Ibidem, Protokół posiedzenia niejawnego Wojskowego Sądu Garnizonowego w Białymstoku w sprawie o sygn. akt G. 132/45 dotyczącej Antoniego Gisztarowicza, 27 VIII 1945 r., k. 14a. 
oraz posiadania broni, nie przyznał się natomiast do przynależności do $\mathrm{AK}^{137}$. Sąd uznał winę Antoniego Giszarowicza co do wszystkich zarzucanych mu czynów, przy czym określił, że uchylał się on od obowiązkowej służby wojskowej w okresie od września 1944 r. do 7 lipca 1945 r. i skazał na podstawie art. 1 Dekretu o Ochronie Państwa na karę 6 lat więzienia, a na poczet orzeczonej kary zaliczył skazanemu okres aresztu tymczasowego od 10 lipca do 31 sierpnia 1945 r.. Ponadto orzekł utratę praw publicznych i obywatelskich praw honorowych na okres 3 lat. Zgodnie $\mathrm{z}$ adnotacją wyrok był ostateczny i nie podlegał zaskarżeniu ${ }^{138}$. 17 września 1945 r. prokurator Wojskowej Prokuratury Garnizonowej w Białymstoku wydał postanowienie o zastosowaniu amnestii w stosunku do skazanego i na jego mocy w oparciu o przepisy Dekretu o amnestii z dnia 2 sierpnia 1945 r. kara została złagodzona do roku więzienia ${ }^{139}$.

Z kolei Jan Jóźwicki thumaczył się w ten sposób:

Ja od służby wojskowej uchylałem się dlatego, że poszedłem za przykładem swoich kolegów, którzy również nie stawili się na komisję poborową, jak również sprawa służby wojskowej według mego zdania była dla mnie zbyteczna ${ }^{140}$.

Podczas przesłuchania przez funkcjonariusza PUBP w Białymstoku Mariana Kutyłowskiego 9 sierpnia 1945 r. Jóźwicki przyznał się również do działalności w AK; w organizacji niepodległościowej zajmował się zbieraniem broni pozostałej po działaniach wojennych oraz trzykrotnie pełnił funkcję wartownika w czasie zorganizowanych przez AK akcji mających na celu zdobycie broni palnej i amunicji141. 10 sierpnia 1945 r. Kutyłowski wydał postanowienie o wszczęciu śledztwa wobec Jóźwickiego, który był podejrzany o popełnienie przestępstwa określonego w art. 118 § 1 KKWP w związku z art. $117 \S 1$ i 2 KKWP oraz art. 1, art. 4 § 1 lit a i art. 3 a Dekretu PKWN z 30 października 1944 r. o ochronie Państwa. Tego samego dnia postanowienie zatwierdził Kierownik PUBP w Białymstoku ${ }^{142}$. Art. 3a Dekretu o ochronie Państwa stanowi: „Kto dopuszcza się gwałtownego zamachu na organ państwowy lub samorządowy albo na osobę, współdziałającą z ta-

137 Ibidem, Protokół rozprawy Wojskowego Sądu Garnizonowego w Białymstoku w sprawie o sygn. akt G. 132/45 dotyczącej Antoniego Gisztarowicza, 31 VIII 1945 r., k. 19-20.

${ }_{138}$ Ibidem, Wyrok Wojskowego Sądu Garnizonowego w Białymstoku w sprawie o sygn. akt G 132/45 dotyczącej Antoniego Gisztarowicza, 31 VIII 1945 r. k. 21-22.

139 Ibidem, Postanowienie o zastosowanie amnestii w stosunku do skazanego Antoniego Gisztarowicza wydane przez prokuratora Wojskowej Prokuratury Garnizonowej w Białymstoku, 17 IX 1945 r., k. 27.

${ }^{140}$ AIPN Bi 212/74, Protokół przesłuchania Jana Józwickiego w charakterze podejrzanego przez funkcjonariusza PUBP w Białymstoku, 9 VIII 1945 r., k. 6-7.

${ }^{141}$ Ibidem, k. 7-8.

142 Ibidem, Postanowienie o wszczęciu śledztwa w stosunku do Jana Jóźwickiego sporządzone przez oficera śledczego PUBP w Białymstoku, 10 VIII 1945 r., k. 10. 
kim organem podlega karze więzienia albo karze śmierci"143. 22 sierpnia $1945 \mathrm{r}$. Jóźwicki za uchylanie się od obowiązku służby wojskowej oraz działalność w AK został pociągnięty do odpowiedzialności karnej ${ }^{144}$. Z materiałów archiwalnych wynika również, że już 10 sierpnia 1945 r. oficer śledczy PUBP w Białymstoku sporządził akt oskarżenia w jego sprawie, zarzucając mu uchylanie się od obowiązku służby wojskowej od dnia 27 lipca 1944 r. do chwili sporządzenia aktu oskarżenia, przynależność od marca 1945 r. do AK, w tym posiadanie i przechowywanie broni bez wymaganego zezwolenia, a także trzykrotny udział w akcjach organizowanych przez $\mathrm{AK}^{145}$. Mjr Władysław Olecki zatwierdził akt 15 września 1945 r. i przekazał wraz z aktami sprawy do $W_{S G}{ }^{146} .18$ września 1945 r. odbyło się posiedzenie niejawne sądu, w którym uczestniczyli kpt. Stanisław Tudruj jako przewodniczący, kpt. Józef Popowski i por. Hieronim Kowalski jako sędziowie, protokolant chor. Jadwiga Grencewicz oraz mjr Władysław Olecki jako oskarżyciel publiczny. Sąd postanowił o zatwierdzeniu aktu oskarżenia wniesionego przeciwko Jóźwickiemu, utrzymaniu w mocy dotychczas stosowanego środka zapobiegawczego w postaci aresztu tymczasowego, wyznaczeniu rozprawy na 22 września 1945 r. w lokalu więzienia Karno-Śledczego w Białymstoku i jej przeprowadzeniu z udziałem prokuratora, jednak bez udziału obrońcy z uwagi na „interes państwa”. Na przewodniczącego składu sędziowskiego został wyznaczony kpt. Józef Popowski ${ }^{147}$. Rozprawa odbyła się zgodnie z wcześniejszymi ustaleniami; poza Popowskim obecni byli por. Hieronim Kowalski oraz por. Juliusz Krupski jako sędziowie oraz chor. Lucjan Szałaj jako protokolant, w rozprawie nie brał udziału prokurator ani obrońca. Oskarżony przynał się do winy ${ }^{148}$. Sąd uznał Jóźwickiego winnym uchylania się od obowiązku służby wojskowej od 30 sierpnia 1944 r. do 8 sierpnia 1945 r. oraz tego, że od marca 1945 r. należał do AK, posiadał bez zezwolenia broń palną i amunicję, a także tego, że w lipcu 1945 r. brał trzykrotnie udział w akcjach organizowanych przez AK. Jana Jóźwickiego w oparciu o art. 3 lit. a Dekretu PKWN z 30 października 1944 r. o ochronie Państwa w związku z art. 33 $\S 2$ KKWP skazano na karę śmierci, utratę praw publicznych i obywatelskich praw

${ }_{143}$ Dekret PKWN z dnia 30 października 1944 r. o ochronie Państwa, art. $3 a$.

144 AIPN Bi 212/74, Postanowienie o pociągnięciu do odpowiedzialności karnej Jana Jóźwickiego wydane przez oficera śledczego PUBP w Białymstoku, 22 VIII 1945 r., k. 12.

145 Ibidem, Akt oskarżenia w sprawie przeciwko Janowi Jóźwickiemu sporządzony przez oficera śledczego PUBP w Białymstoku, 10 VIII 1945 r., k. 19-20.

${ }^{146}$ Ibidem, Postanowienie w przedmiocie zatwierdzenia aktu oskarżenia w sprawie przeciwko Janowi Jóźwickiemu i skierowaniu sprawy do sądu wydane przez prokuratora Wojskowej Prokuratury Garnizonowej w Białymstoku, 15 IX 1945 r., k. 21.

${ }^{147}$ Ibidem, Protokół posiedzenia niejawnego Wojskowego Sądu Garnizonowego w Białymstoku w sprawie o sygn. akt G. 187/45 dotyczącej Jana Jóźwickiego, 18 IX 1945 r., k. 24-25.

${ }^{148}$ Ibidem, Protokół rozprawy Wojskowego Sądu Garnizonowego w Białymstoku w sprawie o sygn. akt G. 187/45 dotyczącej Jana Jóźwickiego, 22 IX 1945 r., k. 27-28. 
honorowych na zawsze oraz przepadek całego mienia na rzecz Skarbu Państwa ${ }^{149}$. W tej sprawie Prezydent Krajowej Rady Narodowej skorzystał z prawa łaski ${ }^{150}$ i zamienił Jóźwickiemu karę śmierci na 10 lat więzienia z pozbawieniem praw publicznych i obywatelskich praw honorowych na 5 lat ${ }^{151}$.

2 lipca 1945 r. zeznawał Justyn Seweruk:

ja mam stawić się do wojska i dostałem kartę, że za pięć dni mam się stawić do wojska, a do wojska się nie stawiłem ze względu, że mam żonę i dzieci dwoje $\mathrm{e}^{152}$.

Za niestawiennictwo do wojska oraz przynależność do AK od 20 kwietnia $1945 \mathrm{r}$. do 6 maja 1945 r. Justyn Seweruk 2 września 1945 r. został pociągnięty do odpowiedzialności karnej z uwagi na naruszenie przepisów art. 118 § $1 \mathrm{KKWP} \mathrm{w} \mathrm{zW}$. z art. 117 § 1 i 2 KKWP oraz art. 1 i art. 4 Dekretu PKWN z 30 października 1944 r. o ochronie Państwa ${ }^{153} .4$ września 1945 r. Edward Błażukiewicz ${ }^{154}$, oficer śledczy WUBP w Białymstoku sporządził akt oskarżenia, w którym oskarżył Seweruka o to, że od listopada 1944 r. do 8 maja 1945 r. uchylał się od służby wojskowej oraz o przynależność do AK i posiadanie bez zezwolenia broni palnej ${ }^{155}$. 18 września $1945 \mathrm{r}$. akt ten został zatwierdzony przez prokuratora wojskowego mjr. Oleckiego, a następnie sprawę według właściwości skierowano do WSG ${ }^{156} .25$ września $1945 \mathrm{r}$. sąd na posiedzeniu niejawnym (kpt. Stanisław Tudruj - przewodniczący, por. Hieronim Kowalski i por. Juliusz Krupski - sędziowie, chor. Jadwiga Grancewicz protokolant oraz mjr Władysław Olecki - oskarżyciel publiczny) zatwierdził akt oskarżenia i wyznaczył rozprawę na 25 września 1945 r. w siedzibie Więzienia Karno-Śledczego w Białymstoku, przy czym miała ona odbyć się bez udziału obrońcy,

149 Ibidem, Wyrok Wojskowego Sądu Garnizonowego w Białymstoku w sprawie o sygn. akt G. 187/45 dotyczących Jana Jóźwickiego, 22 IX 1945 r., k. 34.

${ }^{150}$ Prawo łaski przysługiwało Prezydentowi Krajowej Rady Narodowej na mocy art. 1 lit c ustawy z dnia 11 września 1944 r. o kompetencji Przewodniczacego Krajowej Rady Narodowej (Dz.U. z 1944 r. nr 5 poz. 23).

151 AIPN Bi 212/74, Pismo Prezesa Najwyższego Sądu Wojskowego gen. bryg. Aleksandra Tarnowskiego do Szefa Wojskowego Sądu Garnizonowego w Białymstoku, 18 X 1945 r., k. 42.

152 AIPN Bi 212/86, Protokół przesłuchania aresztowanego Justyna Seweruka, 2 VII 1945 r., k. 6.

153 Ibidem, Postanowienie o pociągnięciu do odpowiedzialności karnej Justyna Seweruka wydane przez oficera śledczego WUBP w Białymstoku, 2 IX 1945 r., k. 17.

154 Edward Błażukiewicz s. Michała, ur. 01 VII 1922 r. w Kulowcach, funkcjonariusz organów bezpieczeństwa państwa, przebieg służby dostępny na stronie elektronicznej BIP Instytutu Pamięci Narodowej w zakładce Katalogi Biura Lustracyjnego, https://katalog.bip.ipn.gov.pl/informacje/51608 [dostęp: 07.06.2019].

155 AIPN Bi 212/86, Akt oskarżenia w sprawie przeciwko Justynowi Sewerukow sporządzony przez oficera śledczego WUBP w Białymstoku, 4 IX 1945 r., k. 21-22.

156 Ibidem, Postanowienie w przedmiocie zatwierdzenia aktu oskarżenia przeciwko Justynowi Sewerukowi i skierowaniu sprawy do sądu wydane przez prokuratora Wojskowej Prokuratury Garnizonowej w Białymstoku, 18 IX 1945 r. k. 23. 
nadto utrzymał w mocy dotychczas stosowany wobec oskarżonego środek zapobiegawczy w postaci aresztu tymczasowego. Przewodniczącym rozprawy wyznaczono por. Hieronima Kowalskiego ${ }^{157}$. Rozprawa odbyła się zgodnie z ustalonym terminem, a jej przebieg protokołował plut. Joachim Kaczanowski. Sąd (por. Kowalski jako przewodniczący, kpt. Józef Popowski i por. Juliusz Krupski jako sędziowie, bez udziału prokuratora i obrońcy) uznał Justyna Seweruka winnym uchylania się od obowiązku służby wojskowej, brania udziału w związku mającym na celu obalenie demokratycznego ustroju Państwa Polskiego (jako że Seweruk był szeregowym członkiem AK), a także posiadania od połowy kwietnia 1945 r. do początku maja 1945 r. bez wymaganego zezwolenia broni palnej i amunicji. Na podstawie art. 1 Dekretu o ochronie Państwa z 30 października 1944 r. przy zastosowaniu art. $32 \S 2$ KKWP skazano go na karę 8 lat więzienia. Sąd orzekł ponadto utratę praw publicznych i obywatelskich praw honorowych na okres 3 lat. Po zastosowaniu przepisów Dekretu o amnestii z 2 sierpnia $1945 \mathrm{r}$. kara więzienia została zmniejszona do lat $3^{158}$.

Franciszek Pac podał następującą przycznę niestawienia się do odbycia służby wojskowej:

Ja do służby wojskowej po oswobodzeniu moich terenów i do chwili obecnej nie stawiłem się dlatego, że mając na utrzymaniu starych rodziców nie chciałem ich samotnych zostawiać na łaskę losu ${ }^{159}$.

W trakcie przesłuchania przyznał się również do przynależności do $\mathrm{AK}^{160} .15$ października 1945 r. oficer śledczy PUBP w Białymstoku Kutyłowski sporządził akt oskarżenia, w którym Franciszek Pac został oskarżony o uchylanie się od służby wojskowej w czasie trwania wojny oraz po jej zakończeniu, o aktywny udział w AK od maja 1945 r. do 8 sierpnia 1945 r., posiadanie bez wymaganego zezwolenia broni palnej i amunicji, jak również branie czynnego udziału w akcjach zbrojnych $\mathrm{AK}^{161}$. Akt oskarżenia, po zatwierdzeniu przez wiceprokuratora Wojskowej Prokuratury Garnizonowej w Białymstoku, został przekazany zgodnie z właściwością do $\mathrm{WSG}^{162} .26$ października 1945 r. w lokalu Więzienia Karno-Śledczego

157 Ibidem, Protokół posiedzenia niejawnego Wojskowego Sądu Garnizonowego w Białymstoku w sprawie o sygn. akt G. 212/45 dotyczącej Justyna Seweruka, 25 IX 1945 r., k. 26-27.

158 Ibidem, Wyrok Wojskowego Sądu Garnizonowego w Białymstoku w sprawie o sygn. akt G. 212/45 dotyczącej Justyna Seweruka, 25 IX 1945 r., k. 30-31v.

159 AIPN Bi 212/159, Protokół przesłuchania podejrzanego Franciszka Paca przez oficera śledczego PUBP w Białymstoku, 8 VIII 1945 r. k. 6-7.

160 Ibidem, k. 7.

161 Ibidem, Akt oskarżenia w sprawie przeciwko Franciszkowi Pacowi sporządzony przez oficera śledczego PUBP w Białymstoku, 15 X 1945 r. k. 19-20.

162 Ibidem, Postanowienie w przedmiocie zatwierdzenia aktu oskarżenia i skierowaniu sprawy do sądu w sprawie Franciszka Paca wydane przez wiceprokuratora Wojskowej Prokuratury Garnizonowej w Białymstoku, 22 X 1945 r., k. 21. 
w Białymstoku odbyła się rozprawa, podczas której oskarżony przyznał się do winy ${ }^{163}$. Wyrok wydał sąd w składzie: mjr Józef Popowski jako przewodniczący, por. Hieronim Kowalski i por. Juliusz Krupski jako sędziowie, z udziałem chor. Jadwigi Grancewicz jako protokolanta oraz bez udziału oskarżyciela publicznego i obrońcy. Ciekawe, że „co do niespełnienia obowiązków służby wojskowej Sąd uznał za nieudowodnioną winę oskarżonego co do uchylania się od obowiązku służby wojskowej, albowiem nie ma tu cech przestępstwa $\mathrm{z}$ art. $118 \S 1 \mathrm{w}$ związku z art. 117 § 1 i 2 KKWP"164.

Na podstawie przywołanych spraw nie można jednoznacznie określić wymiaru kary orzekanej przez WSG wobec uchylających się od służby wojskowej; w przypadkach Wacława Matejczyka i Pawła Radziwanowskiego było to 5 lat, a w przypadkach Stanisława Bruszewskiego i Stefana Kajki - rok więzienia. $\mathrm{W}$ pozostałych omówionych sprawach sąd orzekał kary zawierające również sankcje za naruszenie przez oskarżonych innych przepisów prawnych. Można by mówić o wymierzaniu kary „całościowej”, ponieważ wyroki sądu nie mogą nosić miana kary łącznej z uwagi na to, że w żadnej z rozpatrywanych spraw WSG nie orzekł kary za każde popełnione przestępstwo z osobna, mimo że taki obowiązek wynikał z art. 32 § 2 KKWP: „W razie jednoczesnego skazania za kilka przestępstw, sąd wymierza karę łączną, biorąc za podstawę kary, wymierzone z osobna za zbiegające się przestępstwa"165. Główną przyczyną uchylania się od służby wojskowej były względy rodzinne, oskarżeni brali też przykład z innych osób, które nie zgłaszały się do komisji poborowej. Wypada zwrócić uwagę, że w przypadku orzekania kar na podstawie przepisów art. 118 § 1 KKWP w zw. z art. 117 $\S 1$ i 2 KKWP, tj. kary więzienia, dodatkowo orzekano o odbyciu służby wojskowej poprzez skierowanie skazanego do oddziału karnego, przy czym art. $117 \S 2$ KKWP mówi, że jeżeli przestępstwo uchylania się od obowiązku służby wojskowej nastąpiło w czasie wojny (a było tak we wszystkich omówionych sprawach), to sprawca podlega karze więzienia albo karze śmierci, zatem WSG orzekając karę więzienia nie powinien był stosować innej kary zasadniczej w postaci skierowania do oddziału karnego, gdyż przepis, w oparciu o który wymierzano karę, tego nie przewidywał. Wyroki WSG były ostateczne i nie podlegały zaskarżeniu, a rozprawy odbywały się często bez uczestnictwa obrońców albo przy ich biernym udziale. W przypadku osób oskarżonych o popełnienie czynów określonych przepisami Dekretu z 30 października 1944 r. o ochronie Państwa rozprawy odbywały się zwykle w Więzieniu Karno-Śledczym w Białymstoku i z uwagi na ,in-

163 Ibidem, Protokół rozprawy Wojskowego Sądu Garnizonowego w Białymstoku w sprawie o sygn. akt G. 411/45 dotyczącej Franciszka Paca, 26 X 1945 r., k. 25-27.

${ }^{164}$ Ibidem, Wyrok Wojskowego Sądu Garnizonowego w Białymstoku w sprawie o sygn. akt G. 411/45 dotyczącej Franciszka Paca, 26 X 1945 r., k. 31.

${ }^{165}$ Dekret PKWN z dnia 23 września 1944 r. Kodeks Karny Wojska Polskiego, art. 32 § 2. 
teres państwa" bez udziału obrońcy - wszelkie decyzje w tym zakresie zapadały w trakcie posiedzeń niejawnych sądu, mających na celu przygotowanie rozprawy głównej. Decyzje sędziów WSG co do nieobecności obrońcy podczas rozprawy z uwagi na ,interes państwa” stanowiły naruszenie podstawowej zasady, jaką jest prawo oskarżonego do obrony. Celem takiego działania było przede wszystkim ukaranie osób należących do AK.

\section{DRAFT EVASION IN THE JUDICIAL DECISIONS OF THE GARRISON COURT MARTIAL IN BIAŁYSTOK BETWEEN 1944 AND 1945 EXEMPLIFIED BY SELECTED CASES}

\section{Summary}

The article describes the judicial decisions of the Garrison Court Martial in Białystok between 1944 and 1945 in relation to civilians who were avoiding conscription. Nine court cases are analyzed in which persons did not fulfil their duty concerning compulsory military service. Each person was found to be in breach of the provisions of Article 118 $\S 1$ in conjunction with Article $117 \S 1$ and $\S 2$ of the Polish Army Penal Code from September 1944. The accused defended themselves by pointing to family reasons or to the necessity of farmwork as the main reasons behind avoiding military service. The accused were sentenced to long-term prison sentences for the crime of avoiding military service by the Garrison Court Martial in Białystok. Furthermore, several people were sent to a penal military unit in order to complete their military service.

\section{REFUS DU SERVICE MILITAIRE DANS LA JURISPRUDENCE DU TRIBUNAL MILITAIRE DE GARNISON DE BIAŁYSTOK DE 1944 À 1945 SUR L'EXEMPLE DE CERTAINES AFFAIRES}

\section{Resumé}

L'article traite de la jurisprudence du Tribunal militaire de garnison de Białystok de 1944 à 1945 concernant des civiles qui refusaient le service militaire obligatoire. Neuf affaires judiciaires ont été analysées dans lesquelles des personnes, malgré leur devoir de service militaire, avaient manqué à leur obligation, ce qui contrevenait aux dispositions de l'article $118 \S 1$ combiné avec l'article $117 \S 1$ et 2 du Code pénal de l'armée polonaise de septembre 1944. Pour justifier leurs refus du service militaire, les accusés ont principalement invoqué les raisons familiales ou la nécessité de travailler dans une ferme. Pour le crime commis contre le devoir militaire, ils ont été condamnés par le Tribunal militaire de garnison de Białystok à de longues peines de prison. Plusieurs personnes ont également été envoyées à une unité disciplinaire où elles devaient effectuer leur service militaire. 